OPEN ACCESS

Edited by:

Helen Michelle McGettrick,

University of Birmingham,

United Kingdom

Reviewed by:

Jerome Delon,

INSERM U1016 Institut Cochin,

France

Louise Anne Johnson,

University of Oxford, United Kingdom

*Correspondence:

Kristoffer $\mathrm{H}$. Johansen kristoffer.haurum@gmail.com Klaus Okkenhaug ko256@cam.ac.uk

Specialty section:

This article was submitted to

$T$ Cell Biology,

a section of the journal

Frontiers in Immunology

Received: 12 May 2021

Accepted: 19 July 2021

Published: 06 August 2021

Citation:

Johansen KH, Golec DP. Thomsen JH, Schwartzberg PL and Okkenhaug K (2021) PI3K in T Cell Adhesion and Trafficking.

Front. Immunol. 12:708908. doi: 10.3389/fimmu.2021.708908

\section{PI3K in T Cell Adhesion and Trafficking}

\author{
Kristoffer H. Johansen ${ }^{1,2 *}$, Dominic P. Golec ${ }^{2}$, Julie H. Thomsen ${ }^{1}$, \\ Pamela L. Schwartzberg ${ }^{2}$ and Klaus Okkenhaug ${ }^{1 *}$ \\ ${ }^{1}$ Department of Pathology, University of Cambridge, Cambridge, United Kingdom, ${ }^{2}$ Laboratory of Immune System Biology, \\ NIAID, NIH, Bethesda, MD, United States
}

$\mathrm{PI} 3 \mathrm{~K}$ signalling is required for activation, differentiation, and trafficking of T cells. PI3K $\delta$, the dominant PI3K isoform in T cells, has been extensively characterised using PI3K $\delta$ mutant mouse models and PI3K inhibitors. Furthermore, characterisation of patients with Activated PI3K Delta Syndrome (APDS) and mouse models with hyperactive PI3K $\delta$ have shed light on how increased PI3K $\delta$ activity affects $T$ cell functions. An important function of PI3K $\delta$ is that it acts downstream of TCR stimulation to activate the major T cell integrin, LFA-1, which controls transendothelial migration of $T$ cells as well as their interaction with antigen-presenting cells. PI $3 \mathrm{~K} \delta$ also suppresses the cell surface expression of CD62L and CCR7 which controls the migration of $\mathrm{T}$ cells across high endothelial venules in the lymph nodes and S1PR1 which controls lymph node egress. Therefore, PI3K $\delta$ can control both entry and exit of $\mathrm{T}$ cells from lymph nodes as well as the recruitment to and retention of T cells within inflamed tissues. This review will focus on the regulation of adhesion receptors by PI3K $\delta$ and how this contributes to T cell trafficking and localisation. These findings are relevant for our understanding of how PI3K $\delta$ inhibitors may affect $T$ cell redistribution and function.

Keywords: PI3K, integrin, LFA-1, CD62L, CCR7, adhesion, trafficking

\section{INTRODUCTION}

PI3K signalling controls numerous pathways that are involved in regulating trafficking and localisation of $\mathrm{T}$ cells between lymphoid system and organs, and tissues through the circulatory and lymphatic systems. During the process of $\mathrm{T}$ cell migration, integrins are crucial mediators of adhesion and are extended to an open high-affinity conformation following stimulation of chemokine receptors and/or $\mathrm{T}$ cell receptor stimulation. The major integrin expressed on $\mathrm{T}$ cells is Leukocyte Function-associated Antigen 1 (LFA-1), which is expressed on all subsets of T cells as well as other leukocytes, including B cells and neutrophils. LFA-1 mediates T cell transendothelial migration as well as formation of a stable immunological synapse with antigen presenting cells (APC). The mechanistic regulation of LFA-1 affinity has been extensively studied since its discovery in 1981 as a target for monoclonal antibodies inhibiting cytotoxic T cell-mediated killing (1-3), yet many questions remain about its precise regulation and function. Besides LFA-1, several other adhesion molecules are involved in T cell migration, including $\mathrm{L}$-selectin (CD62L) found on naïve $\mathrm{T}$ cell subsets and on central memory $\mathrm{T}\left(\mathrm{T}_{\mathrm{CM}}\right)$ cells. CD62L binds ligands such as GlyCAM-1 and 
CD34 expressed on endothelial cells and is required for efficient naïve $\mathrm{T}$ cell homing to LNs through high endothelial venules (HEV) [reviewed in (4)].

In this article we will review how PI3K signalling regulates $\mathrm{T}$ cell adhesion, migration and localisation by regulating CD62L and LFA-1 affinity, as well as how this can be targeted by PI3K inhibition. Cytokines and chemokines are also essential for coordinating the trafficking of lymphocytes. Of these, the expression of CCR7 and IL7R $\alpha$ (CD127) are negatively controlled by $\mathrm{PI} 3 \mathrm{~K} \delta$ signalling in a FOXO1-dependent manner and will also be considered.

\section{PI3K SIGNALLING IN T CELLS}

Class I PI3Ks phosphorylate the D3-position of the inositol ring of PtdIns $(4,5) \mathrm{P}_{2}\left(\mathrm{PIP}_{2}\right)$ to generate PtdIns $(3,4,5) \mathrm{P}_{3}\left(\mathrm{PIP}_{3}\right) . \mathrm{PIP}_{3}$ is bound by a subset of pleckstrin homology $(\mathrm{PH})$ and other $\mathrm{PIP}_{3}$-binding domains. Proteins with $\mathrm{PIP}_{3}$-binding properties are hence recruited to the membrane resulting in initiation of downstream signal transduction. The class I PI3K subfamily is comprised of class IA PI3Ks (PI3K $\alpha, \mathrm{PI} 3 \mathrm{~K} \beta$, and PI3K $\delta$ ) and class the IB PI3K (PI3K $\gamma)$. The class I PI3Ks are heterodimeric proteins consisting of a regulatory domain (class IA PI3Ks; p85, class IB PI3K; p101) and a catalytic domain $[\mathrm{p} 110 \alpha(\mathrm{PI} 3 \mathrm{~K} \alpha)$, $\mathrm{p} 110 \beta(\mathrm{PI} 3 \mathrm{~K} \beta)$, or p110 $(\mathrm{PI} 3 \mathrm{~K} \delta)$, or p110 $\gamma(\mathrm{PI} 3 \mathrm{~K} \gamma)]$ (5). Class II and class III PI3Ks use PtdIns or PtdIns (4)P as a substrate and are involved in intracellular membrane trafficking, these will not be considered here [reviewed in (6)].
In T cells $\mathrm{PI} 3 \mathrm{~K} \delta$ is the dominant class I PI3K isoform. PI3K $\delta$ is activated downstream of the TCR as well by costimulatory and cytokine receptors, that stimulate the phosphorylation of tyrosines within YXXM motifs that bind to the $\mathrm{SH} 2$ domains of the p85 subunit (7) (Figure 1). Indeed, LFA-1 can also activate $\mathrm{PI} 3 \mathrm{~K} \delta$ via so called outside-in signalling (8). PI3K $\gamma$ is also expressed in $\mathrm{T}$ cells and predominantly mediates signals downstream of $G$ protein-coupled receptors such as chemokine receptors (5) (Figure 1).

\section{PI3K in T Cell Development}

Signalling through class I PI3K plays important roles at multiple stages of $\mathrm{T}$ cell development. Loss of both $\mathrm{p} 110 \delta$ and $\mathrm{p} 110 \gamma$ results in near complete ablation of thymocyte $\beta$-selection, while individual loss of $\mathrm{p} 110 \delta$ and $\mathrm{p} 110 \gamma$ individually only causes minor perturbations of $\mathrm{T}$ cell development (9-11). These findings revealed an unexpected redundancy between $\mathrm{p} 110 \delta$ and $\mathrm{p} 110 \gamma$ in developing $\mathrm{T}$ cells and was explained by cooperative signalling from the chemokine receptor CXCR4 via $110 \gamma$ and pre-TCR signalling via $110 \delta$, either of which is sufficient to generate $\mathrm{PIP}_{3}$ required during thymocyte $\beta$-selection (12). Consistent with this, deleting the $\mathrm{PIP}_{3}$ phosphatase PTEN bypasses the requirement for pre-TCR stimulation during thymic $\beta$-selection, presumably by enabling sustained CXCR4dependent $\mathrm{PIP}_{3}$ levels (13). Beyond thymocyte $\beta$-selection, mice lacking PTEN show impaired thymocyte negative selection and evidence of autoimmunity, suggesting a role for PI3K activity in maintaining central tolerance (14). In addition, mice expressing a kinase-dead p110 $\delta$ show increased numbers of Treg within the

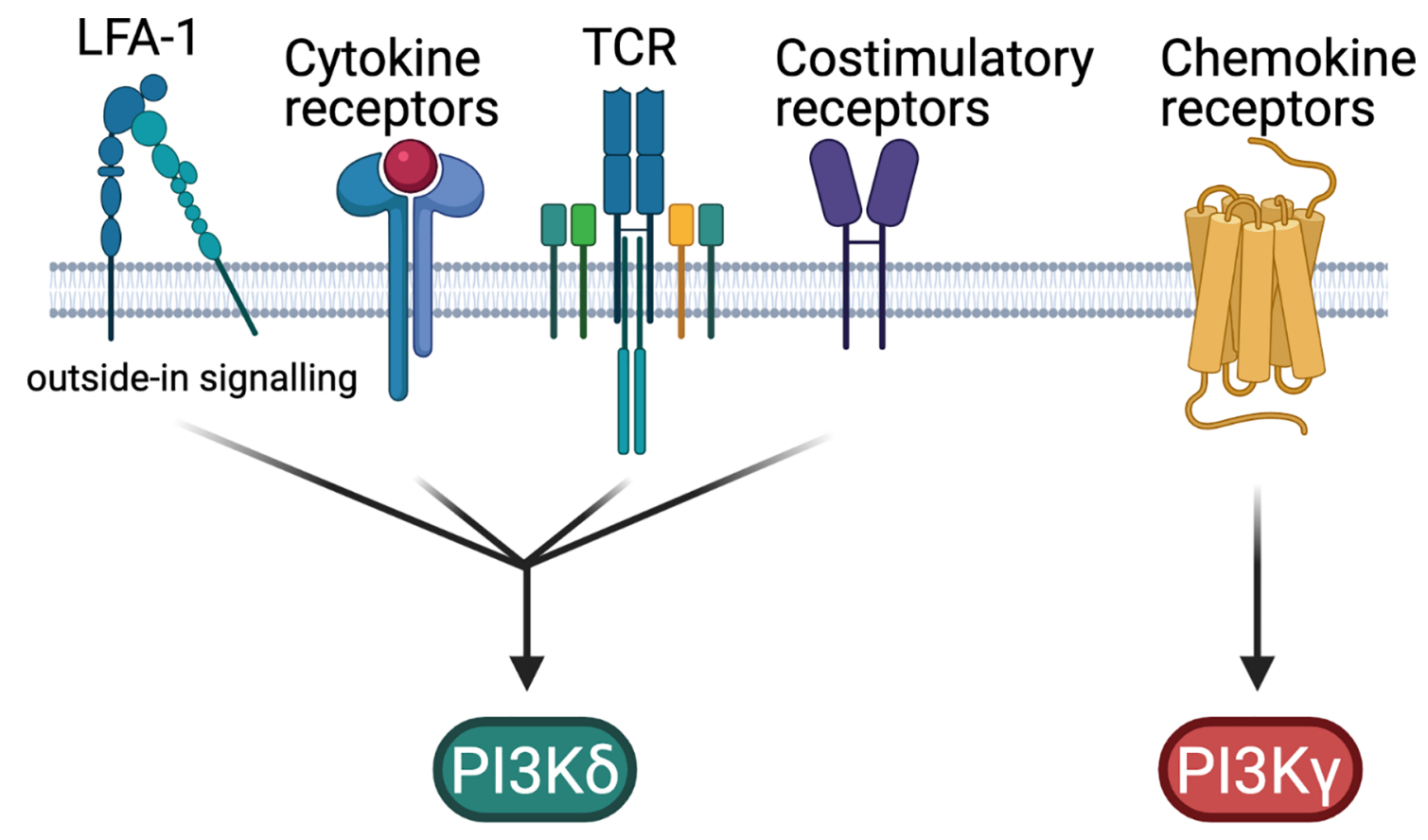

FIGURE 1 | PI3K activation in T cells. Simplified schematic of the differential regulation of PI3K $\delta$ and PI3K $\gamma$ in T cells. Figure made in BioRender. 
thymus, highlighting a role for $\mathrm{p} 110 \delta$ in thymic $\mathrm{T}_{\text {reg }}$ selection (15). Together these findings underpin an important role for PI3K signalling in the development of T cells.

Following thymic development, class I PI3K signalling is also crucial for the peripheral development of multiple subsets of $\mathrm{T}$ cells; $\mathrm{T}$ follicular helper cells $\left(\mathrm{T}_{\mathrm{FH}}\right.$ cells) require ICOS signalling during development, and ICOS mutant mice that do not activate downstream PI $3 \mathrm{~K} \delta$, as well as mice lacking $\mathrm{p} 110 \delta$ in T cells, lack $\mathrm{T}_{\mathrm{FH}}$ cells $(16,17)$. The loss of $\mathrm{T}_{\mathrm{FH}}$ cells is the main reason underpinning the lack of germinal centres and immunoglobulin class switching after immunisation of PI3K $\delta$-deficient mice (16). PI3K $\delta$ also regulates the differentiation of other $\mathrm{T}_{\mathrm{H}}$ subsets, including $\mathrm{T}_{\mathrm{H}} 1, \mathrm{~T}_{\mathrm{H}} 2, \mathrm{~T}_{\mathrm{H}} 17$, and $\mathrm{T}_{\text {reg }}$, as well as production of cytokines and granzymes in both $\mathrm{CD}^{+}$and $\mathrm{CD}^{+} \mathrm{T}$ cells $(15$, 18-26). Human patients with loss of function mutations in PI3K $\delta$ have also been identified (27-30). These have a more profound defect in B cell development than observed in mice. By contrast, profound defects in T cell development have not been observed so far in patients lacking the $\mathrm{p} 85 \alpha$ or $\mathrm{p} 110 \delta$ subunits of $\mathrm{PI} 3 \mathrm{~K} \delta$; but this has been difficult to evaluate systematically in such immune-deficient patients who also suffer from inflammatory disease.

\section{Activated PI3K $\delta$ Syndrome}

More recently, gain-of-function mutations that lead to increased $\mathrm{PI} 3 \mathrm{~K} \delta$ activity have also shown to be the cause of a novel immunodeficiency syndrome called Activated PI3K delta Syndrome (APDS) (31-35). APDS patients show increased susceptibility to airway infections (e.g. with Streptococcus Pneumoniae), chronic virus infections (CMV and EBV) and pertinent to this review, have enlarged LNs and spleens as well as signs of autoimmunity, mainly manifested as cytopenia (34). Remarkably after a 12 -week trial of the PI3K $\delta$ inhibitor Leniolisib, the LNs and spleens of these patients reduced in size by up to $50 \%$ (36). This may reflect in part the potential of $\mathrm{PI} 3 \mathrm{~K} \delta$ inhibitors to cause redistribution of lymphocytes in addition to the inhibitory effect on lymphocyte proliferation. Several groups have generated mouse models of APDS which recapitulate many of the features of the patients, including increased susceptibility to airway infections, enlarged LNs and spleen and production of autoantibodies (37-41). Altogether, these studies shine light on the paradox that both loss-of-function and gain-of-function of PI $3 K \delta$ leads to immunodeficiency, and highlight how this pathway needs to be dynamically regulated for optimal lymphocyte development and function $(42,43)$. This, as we will see, is also key for the control of lymphocyte trafficking.

Currently four different PI3K $\delta$ inhibitors are approved for the treatment of B cell malignancies (44). A detailed description of these is beyond the remit of this review, however two concepts learned from the treatment of these patients are worth noting. Chronic lymphocytic leukaemia (CLL) patients treated with $\mathrm{PI} 3 \mathrm{~K} \delta$ inhibitors such as Idelalisib initially experience a dramatic redistribution of the malignant $B$ cells from the LNs (45). This phenomenon is referred to as lymphocytosis and is now recognised as a beneficial clinical feature of this class of drugs. Lymphocytosis is thought to be secondary to the interference with BCR-dependent integrin activation and chemokine responsiveness (46). CLL cells that are purged from their protective $\mathrm{LN}$ environment are more susceptible to undergo apoptotic cell death which can be accelerated with chemotherapy or drugs such as rituximab (anti-CD20) (45). Immune-mediated colitis and hepatitis are common adverse effects of PI3K $\delta$ inhibitors, but skin inflammation is also seen in some studies (47). These are thought to be caused by the selective depletion or inactivation of Tregs, especially from tissues with high exposure to microbial antigens, such as the gut, liver and skin $(44,48)$. In this context, by targeting Treg, PI $3 K \delta$ inhibitors can unleash potent antitumour immune responses (49). Recent evidence suggests that PI3K $\delta$ inhibitors can purge Treg from the tumour microenvironment and into the circulation (50). Hence the capacity of PI3K $\delta$ inhibitors to not only affect lymphocyte function, but also to cause redistribution out of lymphoid tissues may underpin the therapeutic effects of $\mathrm{PI} 3 \mathrm{~K} \delta$ inhibitors.

\section{INTEGRINS IN T CELL LOCALISATION, MIGRATION, AND ADHESION}

Integrins are transmembrane, heterodimeric proteins that are involved in cell-cell and cell-extracellular matrix interactions as well as binding of soluble ligands. In mammals the heterodimeric transmembrane structure of integrins is composed of one of $18 \alpha$ subunits and one of eight $\beta$ subunits, that can form up 24 combinations. Integrins are involved in $\mathrm{T}$ cell migration and localisation within tissues, where conformational priming (activation) of the integrins by intracellular signalling events ("Inside-out" signalling) results in high affinity binding of their ligands. Further, integrins mediate signal transduction, where binding of their ligands stimulates intracellular signalling pathways ("outside-in" signalling).

$\mathrm{T}$ cells are known to express at least 15 of the 24 known integrins depending on their differentiation and activation state $(51,52)$ (Figure $2 \mathbf{A})$. LFA-1 $(\alpha \mathrm{L} \beta 2)$ is expressed by all $\mathrm{T}$ cell subsets and specifically binds Intercellular Adhesion Molecules (ICAMs) and Junctional Adhesion Molecules (JAMs) $(53,54)$. Under steady state, LFA-1 is found in a closed conformation which has low affinity for its ligands. However, following insideout mediated activation by chemokines, cytokines, or TCRstimulation, LFA-1 rapidly changes conformation from its low affinity closed/bent conformation to an intermediate affinity extended conformation, where the extracellular domain is partly open, but the cytosolic domain remains closed. This intermediate affinity extended conformation allows for binding to ICAM-1, which can further increase affinity through outsidein signalling resulting in the high affinity open-extended conformation (Figure 2B) reviewed in (51, 55). Multiple other integrins are expressed in subsets of T cells, including Very Late Antigen 4 (VLA-4) ( $\alpha 4 \beta 1$ ) which binds VCAM-1, however in this review we will focus on the roles of LFA-1. 
A

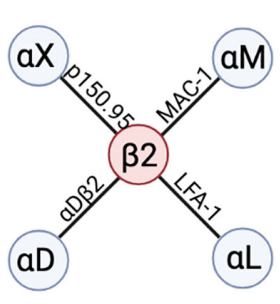

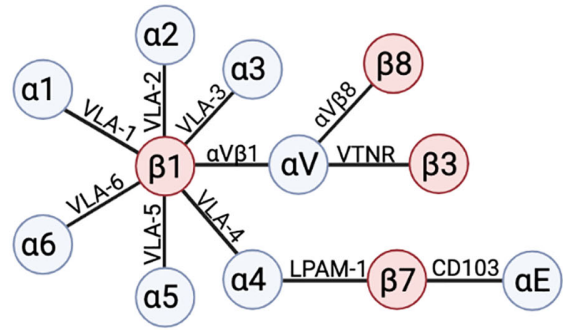

B

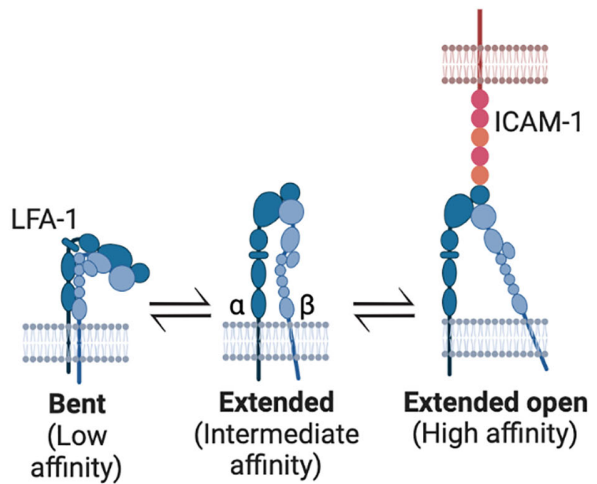

FIGURE 2 | Integrins in T cells. (A) Schematic of integrin chains expressed in T cells with $\alpha$ integrin chains in blue, and $\beta$ integrin chains in red. Lines indicate which integrin chains form heterodimeric integrins, and names over lines are commonly used names of the resulting integrin. (B) LFA-1 ( $\alpha L \beta 2$ ) integrin in a bent/closed conformation with low affinity, extended/closed conformation with intermediate affinity, and extended open conformation with high affinity. Figure made in BioRender.

\section{Integrins in T Cell Migration}

$\mathrm{T}$ cells recirculate between LNs through the blood, probing antigen-presenting cells for their cognate antigen. To exit blood vessels, selectins, integrins, and chemokines are required to halt the $\mathrm{T}$ cells at the right place and resist the shear stress in the blood (1-70 dyn $\left./ \mathrm{cm}^{2}\right)(56)$. This is a tightly regulated process. Selectin-mediated binding of their ligands facilitates rolling along the endothelial membrane which slows down the $\mathrm{T}$ cells. This allows the $\mathrm{T}$ cells to respond to chemokines secreted from the endothelia and immobilised on glycosaminoglycans (GAGs) on the surface of the endothelial cells Reviewed in (57). As a result, integrins (such as LFA-1 and VLA-4) are activated. LFA-1mediated binding of endothelial ICAMs (ICAM-1 and -2) leads to firm adhesion to the endothelial barrier. This allows the $T$ cells to crawl against the flow towards chemotactic gradients until the cell will undergo transendothelial migration (TEM, also termed diapedesis) through the endothelial barrier into the underlying tissue.

Recirculation and homing of naïve $\mathrm{T}$ cells to secondary lymphoid organs (SLOs), including LNs, requires expression of the chemokine receptor CCR7 and CD62L, both which are downregulated following PI3K activation as discussed later. CD62L interacts with peripheral node addressins (PNAds) expressed on high endothelial venules (HEVs) which are formed by specialised endothelial cells lining post-capillary venules associated with lymph nodes (LNs). The interaction between CD62L and PNAd causes T cells to start rolling along the HEVs. After slowing down, CCR7 on the T cells binds CCL21 presented by HEVs $(58,59)$, which rapidly induces LFA-1 activation, leading to arrest and transendothelial migration (60, 61). The process of LN entry is highly dependent on LFA1; LFA1-deficient mice have greatly reduced adhesion to HEVs, particularly in peripheral LNs (pLNs) and therefore elicit limited to no migration to the LNs $(62,63)$. Similarly, LFA-1blocking antibodies block adhesion to HEVs and prevent repopulation of LNs (64). Together, HEVs thus function as a selective gateway to the LNs, attracting naïve and resting memory $\mathrm{T}$ cells, but largely blocking entry of other leukocytes such as neutrophils under steady state (65). Migration to gutassociated lymphoid tissues, spleen and inflamed lymphoid tissues are governed by other mechanisms and molecules, such as $\alpha 4 \beta 7 /$ MAdCAM- 1 interactions, and this integrin seems to be regulated by different pathways than LFA-1 and VLA-4 (66). After entering LNs, the role of LFA-1 is less clear; studies of LFA1-deficient T cells indicate that LFA-1 is required for retention of $\mathrm{T}$ cells in the parenchyma (67). However, other studies using LFA-1-deficient T cells (68) or dendritic cells lacking integrins altogether (69), suggest that interstitial and intranodal motility of $\mathrm{T}$ cells and DCs in the absence of antigen is much less dependent on integrins than is the entry into and egress out of the LNs.

Following screening of antigen within the LNs, T cells will egress through the efferent lymphatics in a process regulated by LFA-1/ICAM-1-interactions (67). Egress is guided by the lipid sphingosine-1-phosphate (S1P). S1P is found in low concentrations inside the LNs, but high concentrations in lymph and blood, creating a gradient which attracts the $\mathrm{T}$ cells through binding of the GPCR S1P receptor 1 (S1PR1) expressed by naïve $\mathrm{T}$ cells (70). Following egress through efferent lymphatics, the lymphatics connect LNs in series, but eventually merge with the thoracic duct allowing the $\mathrm{T}$ cells to recirculate through the blood. Interestingly, S1P-mediated egress from inflamed tissues is also partially dependent on interactions between LFA-1/ICAM-1 and VLA-4/VCAM-1. Here LFA-1/ ICAM- 1 are required for effective migration of memory $\mathrm{T}$ cells through afferent lymphatics into LNs (71-73).

Antigen-stimulated $\mathrm{T}$ cells downregulate L-selectin and glycosylate P-selectin glycoprotein ligand-1 (PSGL-1) resulting in functional PSGL-1 ligand which allows for binding of L-, P-, and E-selectins that are upregulated on inflamed endothelial tissues reviewed in (4). Other integrins are also involved in migration along, and adhesion to vascular endothelium as well as transendothelial migration of antigen-stimulated $\mathrm{T}$ cells. 
Of particular importance are VLA-4/VCAM-1, $\alpha 4 \beta 7 /$ MAdCAM-1, and $\alpha \mathrm{V}$ integrin-mediated (74) interactions that facilitate migration to distinct inflammatory sites reviewed in $(75,76)$.

\section{Integrins in the Immunological Synapse}

Within the T cell follicles of the LNs, T cells recognise their cognate antigen-MHC complex on the surface of antigen presenting cells (APCs) or target cells. This induces TCR signalling and triggers the formation of an immunological synapse (IS) at the contact area between the T cell and the APC/target cell (77). The IS is a highly specialised and dynamic cell-cell interface that allows for fine-tuning of signalling events leading to $\mathrm{T}$ cell activation $(78,79)$. Integrins and especially LFA-1 are key components in IS formation. In the immature IS, PI3K-dependent chemokine-mediated LFA-1 activation initiates the adhesive contact between $\mathrm{T}$ cells and APCs/target cells allowing the $\mathrm{T}$ cell to scan its interaction partner for cognate antigens (80). Concomitantly, LFA-1 triggers recruitment of organelles such as mitochondria to the IS thereby preparing the $\mathrm{T}$ cell for optimal TCR-induced activation and $\mathrm{Ca}^{2+}$ signalling during later activation stages (80).

In the immature IS, LFA-1 is found at the centre of the synapse with TCRs and downstream kinases clustered at the periphery $(81,82)$. During maturation of the IS, the synapse is reorganised into annular supramolecular clusters (SMACs) allowing for spatiotemporal clustering of receptors, adhesion molecules, and signalling effector proteins (Figure 3A) (83). In the mature IS, centripetal movement relocates $\mathrm{TCR} / \mathrm{pMHC}$ complexes to the central SMAC (cSMAC) together with their co-stimulatory molecules, intracellular kinases, and adaptor proteins. Simultaneously, LFA-1/ICAM-1 complexes are redistributed to the integrin-enriched peripheral SMAC (pSMAC) surrounding the cSMAC (81). In the pSMAC, LFA-1 both stimulates $\mathrm{T}$ cell activation by increasing the accumulation of TCR/pMHC complexes in the cSMAC, and recruiting signalling molecules to the pSMAC; LFA-1 may also help segregate the phosphatase CD45 to the distal SMAC (dSMAC)
$(84,85)$. In addition to LFA-1, the $\alpha 4 \beta 1$ integrin, VLA-4, is also enriched in the pSMAC and is involved in T cell activation by regulating the mobility of SLP-76, an essential adaptor protein functioning downstream the TCR (86). It is thought that VLA-4 can restrain SLP-76 in the PSMAC, so that SLP-76 both remains in closer contact with its upstream activators and avoids the cSMAC, where signalling complexes will eventually be internalised and degraded to terminate TCR signalling $(86,87)$. Collectively, an important function of integrins in the IS appears to be regulating the localisation of both inhibitory and stimulatory signalling molecules. The phosphatidylinositol (PIP) composition of the IS might also contribute to this spatial regulation of signalling proteins within the IS (Figure 3B). Early studies confirmed the accumulation of $\mathrm{PIP}_{3}$ inside and outside the IS between APCs and T cells (88-90). However, $\mathrm{PIP}_{3}$ seemed less concentrated at the cSMAC, and later studies using transgenic $\mathrm{CD}^{+} \mathrm{T}$ cells have found that PI3Kgenerated $\mathrm{PIP}_{3}$ seems specifically accumulated in the periphery of the IS (91-93). Further, both $\mathrm{PIP}_{2}$ and $\mathrm{PIP}_{3}$ are cleared from the cSMAC during conjugate formation, and sustained PI3K activity is necessary for proper $\mathrm{T}$ cell activation possibly through the regulation of $\mathrm{PIP}_{3}$ binding proteins (91-93). It has further been suggested that PI3K-dependent actin remodelling in the periphery of the IS can mediate synaptic force on the target cell thereby potentiating target cell killing by $\mathrm{CD}^{+} \mathrm{T}$ cells (94).

\section{Integrin Affinity Regulation in T Cells}

Inside-out signalling in $\mathrm{T}$ cells is a complex process mediated by a range of proteins that collectively result in increased LFA-1 affinity and avidity. Following TCR stimulation, multiple proteins are recruited to phosphorylated CD3 ITAMs, including the tyrosine kinase ZAP-70. ZAP-70 consequently phosphorylates tyrosine residues of the scaffolding protein LAT. These residues act as anchors for a range of $\mathrm{T}$ cell signalling proteins, including SLP76, which is also phosphorylated by ZAP-70. The pSLP76/LATcomplex functions as a scaffold for downstream effector
A

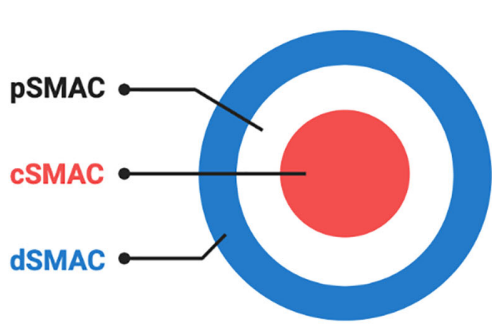

B

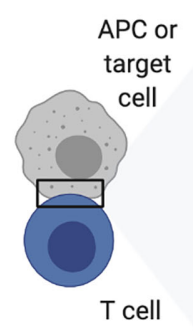

Mature Immunological Synapse

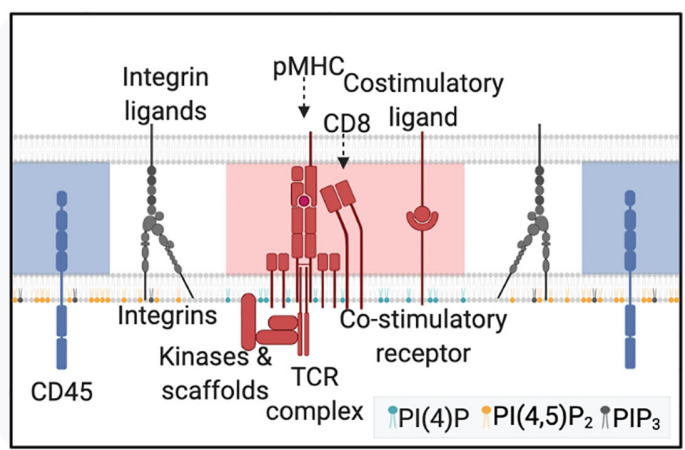

FIGURE 3 | Phospholipids in the immunological synapse. (A) shows the bulls eye of the synapse in the Z-plane. (B) Schematic of the immunological synapse showing approximate location of critical receptors in the distal SMAC (dSMAC), peripheral SMAC (pSMAC), and central SMAC (cSMAC) as well as approximate composition of the phosphoinositols $\mathrm{PI}(4) \mathrm{P}, \mathrm{PI}(4,5) \mathrm{P}_{2}$ and $\mathrm{PI}(3,4,5) \mathrm{P}_{3}$ in the inner leaflet of the $\mathrm{T}$ cell. Figure made in BioRender. 
proteins, including PLC $\gamma$ (95). PLCs catalyse the hydrolysis of $\mathrm{PIP}_{2}$ to generate the second messenger signalling molecules diacylglycerol (DAG) and inositol 3-phosphate $\left(\mathrm{IP}_{3}\right)$. In turn, $\mathrm{IP}_{3}$ stimulates the release of $\mathrm{Ca}^{2+}$ from the endoplasmic reticulum (ER). $\mathrm{Ca}^{2+}$ and DAG stimulate activation of the RAP1 guanine exchange factor (GEF), CalDAG-GEFI (also known as RASGRP2) which activates RAP proteins by exchanging GDP for GTP (96). In T cells, RAP1 is a dominant isoform, with both Rapla and Rap1b being expressed. Of note however, CalDAGGEFI is not expressed in mouse lymphocytes, suggesting other RAP GEFs are involved in the regulation. Another pathway leading to RAP1 activation is recruitment of the CRKL-C3G complex by the WAVE2-Arp2/3-Abl complex (97, 98). This results in activation of the RAP-GEF, C3G (Also known as RAPGEFI), thus further activating RAP1. Active GTP-bound RAP1 is critical for the process of LFA-1 activation (99-103).

Chemokine receptors are GPCRs that following chemokine binding induce a multitude of signals, some which converge in activation of the small GTPase RAP1 via the activation of phospholipase $\mathrm{C} \beta$ (PLC $\beta$ ) which also hydrolyses $\mathrm{PIP}_{2}$ to $\mathrm{DAG}$ and $\mathrm{IP}_{3}$ (104-106). Besides activating the PLC-dependent signalling-cascade, chemokine receptors also induce activation of $\mathrm{PI} 3 \mathrm{~K} \gamma$ resulting in initiation of PI3K-mediated signals discussed further below.

GTP-bound RAP1 interacts with RIAM (107-109) and RAPL (100). In turn, this complex mediates activation (109), and plasma-membrane binding of TALIN1 (108). The FERM3 (F3) domain of TALIN1 in turn binds the $\beta$ chain of LFA- 1 thereby mediating conformational activation of LFA-1 from low to intermediate affinity, as well as mediating downstream cytoskeletal remodelling $(110,111)$. RIAM has a PH domain that preferentially interacts with PIP $_{2}$. By binding PIP 2 RIAM is thought to act as a proximity detector mediating binding of activated RAP1 and TALIN1 to the membrane (112). Another $\mathrm{PH}$-domain containing protein involved in the process is SKAP1 (also known as SKAP55). SKAP1 is constitutively associated with ADAP (also known as FYB) and has been shown to also mediate binding of RAP1 to the plasma membrane through its $\mathrm{PH}$ domain $(113,114)$. Together SKAP1/ADAP integrates with the RIAM-RAPL-RAP1 complex during TCR-induced LFA-1 activation, and likely stabilises the complex (115). In parallel during LFA-1 activation, KINDLIN-3 binds the cytoplasmic tail of $\beta$ integrins and is required for stabilisation of the high affinity conformation of LFA-1 (116-118). TALIN1 thus mediates conformational maturation to an intermediate affinity of LFA1 , whereas binding of both KINDLIN-3 and TALIN1 to the $\beta$ chain results in the high affinity conformation of LFA-1 (116).
Several negative regulators of LFA-1 activation exist. RhoH is required to keep LFA-1 in a non-adhesive state (119). RhoH also contributes to TCR signalling by interacting with ZAP70 and LCK (120, 121). Interestingly, chemokine-induced LFA1 activation is suppressed by $\mathrm{RhoH}$, whereas $\mathrm{RhoH}$ enhances TCR-induced LFA-1 activation, suggesting that RhoH can divert $\mathrm{T}$ cells from chemotactic towards antigen-dependent response (122). CBL-B is an E3 is ubiquitinase that can suppress LFA-1 activation by interfering with the capacity of CRK-L to recruit and activate C3G (123).

Together these intricate regulatory mechanisms integrate migratory signals, such as chemokines, and TCR engagement with integrin activation. Consequently, LFA-1 affinity is turned on and off in a highly regulated manner by multiple microenvironmental cues.

\section{PI3K-MEDIATED ACTIVATION OF INTEGRINS - A GATEKEEPER OF ANTIGEN-DEPENDENT ADHESION}

Early studies of PI3Ks roles in $\mathrm{CD} 4^{+} \mathrm{T}$ cell activation found that broad inhibition of PI3Ks with Wortmannin reduced antigenspecific interactions between DO11.10 $\mathrm{CD}^{+} \mathrm{T}$ cells and OVApulsed B cells, as well as T cell adhesion to immobilised ICAM-1 (ICAM-1-coated plastic) $(124,125)$. Further, Wortmannin was found to inhibit CD28-induced activation (126), and Wortmannin and LY294002 (class I PI3K inhibitor) inhibit CD7-induced activation of $\beta 1$-integrin-mediated adhesion (VLA1-6) to immobilised fibronectin (127). In accordance, overexpression of a hyperactive p110-CAAX mutant increased ICAM-1-binding in response to PDBu/Ionomycin (95). These early findings all supported a role for PI3K in activation of integrins downstream of TCR-engagement, although caution must be taken with some of these inhibitor studies, as that Wortmannin can affect multiple kinases. Further, caution must be taken when evaluating affinity vs avidity in these studies (Box 1).

Further supporting a role for PI3K in integrin activation, kinase-dead $\mathrm{p} 110 \delta^{\mathrm{D} 910 \mathrm{~A}} \mathrm{CD} 4^{+} \mathrm{T}$ cells had reduced affinity towards ICAM-1 after stimulation with anti-CD3, as measured by binding of soluble recombinant ICAM-1 by flow cytometry. As a consequence, OT-II transgenic $\mathrm{p} 110 \delta^{\mathrm{D} 910 \mathrm{~A}} \mathrm{CD} 4^{+} \mathrm{T}$ cells did not form conjugates with $\mathrm{OVA}_{323-339}$-pulsed $\mathrm{B}$ cells as well as WT OT-II T cells. p1 $10 \delta^{\mathrm{D} 910 \mathrm{~A}}$ mutant T cells had reduced RAP1GTP, indicating a role for PI3K $\delta$ in RAP1-GTP activation.

\footnotetext{
BOX 1 | Affinity Contra Avidity of Integrins - Note of Caution.

When studying integrins such as LFA-1, regulation can either be modulated by direct changes to affinity by inside-out signalling and outside-in signalling, changes in avidity through surface clustering of the integrins, and lastly by levels of expression or presence at the surface. Studies investigating LFA-1-mediated adhesion often do not clearly distinguish these mechanisms and it is often unclear whether particular mechanisms affect LFA-1 affinity or avidity.

In human T cells antibodies specific to the intermediate or high affinity conformation of LFA-1 can be used to measure affinity, however similar affinity-specific antibodies are not as well established for mouse T cells. Binding of ICAM-1 can be used as a proxy for LFA-1 activity and here binding to single ICAM-1 molecules is more dependent on affinity changes and LFA-1 surface expression, whereas binding of ICAM-1-coated surfaces (immobilised ICAM-1) or conjugate-formation is dependent both on changes to overall avidity as a result of increased affinity, surface expression, and clustering.
} 
Interestingly, the activation of LFA-1 was less dependent on AKT suggesting other $\mathrm{PIP}_{3}$-binding proteins were responsible for the PI3K-mediated activation of LFA-1 (128).

Treatment of lymphocytes with Wortmannin or LY294002 decreases SDF1 $\alpha$, CCL19, and CCL21-mediated adhesion to ICAM-1. However, this decrease seemed to rather be a consequence of decreased avidity than affinity as a result of decreased chemokine-induced LFA-1 mobility following PI3K inhibition (60). Indeed, chemokine-dependent migration of $\mathrm{T}$ cells was largely PI3K $\gamma$-independent and instead mediated by DOCK2 (129). Similarly, interstitial migration and S1P-mediated egress was independent of PI3K $\gamma(130)$. PI3K $\delta$ signalling was also not required for chemokine-induced LFA-1 activation (128). Therefore, PI3K $\delta$ activity downstream of TCR-stimulation increases LFA-1 affinity, whereas PI3K $\gamma$-signalling seems dispensable for chemokine-induced LFA-1 affinity regulation.

\section{Regulation of LFA-1 by PH-Domain Containing Proteins}

Multiple proteins involved in the process of LFA-1 activation, including CYTOHESIN-1, SKAP1, and KINDLIN-3, have PH domains that bind $\mathrm{PIP}_{3}$ and may hence regulate LFA-1 affinity in a PI3K dependent manner (Figures 4A, B).

\section{CYTOHESINS}

The intracellular ARF-GEF protein, CYTOHESIN-1, was described early on to bind $\beta 2$ integrins (e.g. LFA-1, MAC-1) and activate LFA-1-mediated adhesion to immobilised ICAM-1. The PI3K-mediated membrane recruitment of the $\mathrm{PH}$ domain of CYTOHESIN-1 was found to partially facilitate the CYTOHESIN1-mediated activation of LFA-1 (132-134). CYTOHESIN-1 binds directly to the cytoplasmic tail of $\beta 2$ integrin, and this interaction as well as the ARF-GEF functionality of its SEC7 homology domain have been shown to regulate the activation of LFA-1 in T cells and LFA-1 mediated transendothelial migration $(135,136)$. Moreover, CYTOHESIN-1 further regulates activation of RhoA and integrin activation in dendritic cells (137). Surprisingly, CYTOHESIN-1 seems to have opposing roles in regulation of MAC-1 $(\alpha M \beta 2)$ integrin-mediated adhesion to fibrinogen by neutrophils, suggesting a more complex involvement of CYTOHESIN-1 in regulation of integrin activation (138). This potentially hints a differential role of PI3K-signaling in regulating integrins in different immune subsets depending on their integrin expression. Other CYTOHESIN molecules have also been implicated in integrin regulation, but rather seem to rather be involved in the recycling of integrins from the surface. Whereas CYTOHESIN-2 (ARNO) seems to increase $\beta 1$ integrin-mediated adhesion and recycling, CYTOHESIN-3 (GRP1) results in decreased adhesion (139), and these opposing effects of CYTOHESIN-2 and -3 were dependent on phosphoinositide specificity (140). How the CYTOHESINs divergently regulate integrins, and further, the mechanism by which PI3K regulates CYTOHESIN-1-mediated LFA-1 activity is still unclear, but it is likely due to dominant negative effects between the different
A

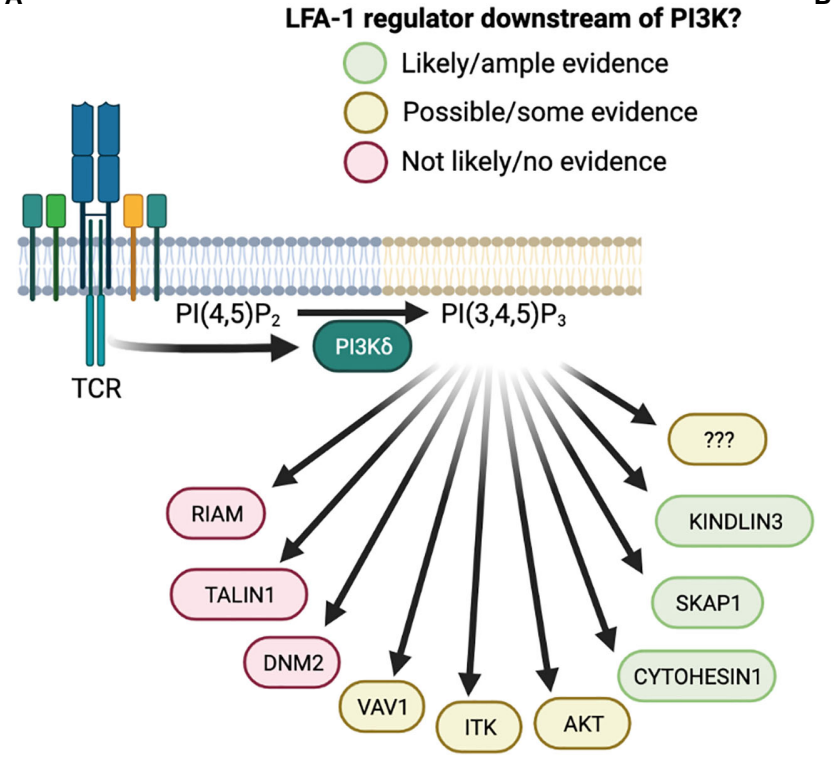

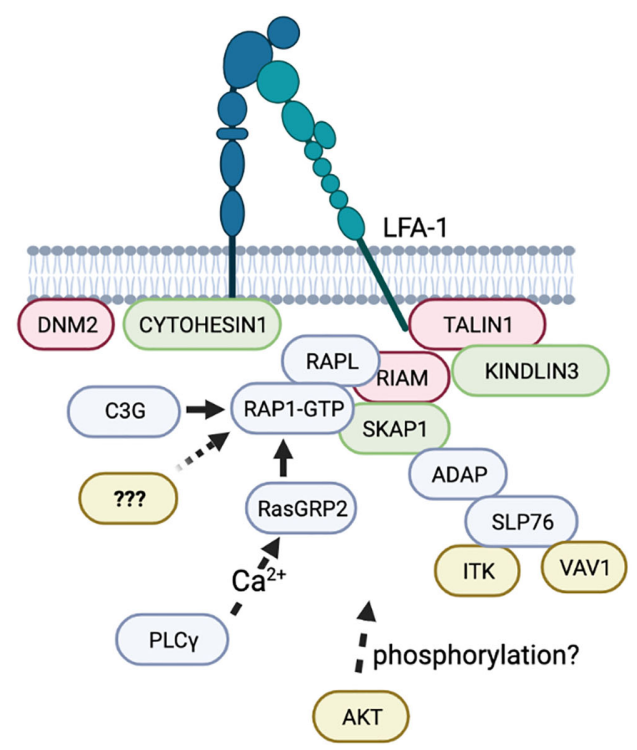

FIGURE 4 | LFA-1 regulators downstream of PI3K $\delta$. (A) Schematic of proteins that have been implicated in LFA-1 regulation, and the likelihood that they are regulated by PI3K based on the literature. Green proteins have ample evidence that they are regulated by PI3K and have been implicated in LFA-1 regulation in multiple studies. Orange proteins have some evidence suggesting that PI3K regulates their functions and are to some extent involved in LFA-1 regulation. Red proteins have PH domains, but are unlikely to be regulated by PI3K due to low $\mathrm{PIP}_{3}$ affinity. It is important to note that $\mathrm{PIP}_{2}$ is up to $100 \mathrm{X}$ more abundant on the plasma membrane than $\mathrm{PIP}_{3}$ (131). Therefore, a given protein needs to have high selectivity for $\mathrm{PIP}_{3}$ over $\mathrm{PIP}_{2}$ in order to be directly regulated by PI3Ks. (B) Simplified schematic of how the proteins in (A) are involved in regulation of LFA-1, showing interaction partners and approximate location. Figure made in BioRender. 
homologs, and should highlight the importance of not treating all integrin signalling pathways equally.

\section{SKAP1}

SKAP1 is recruited to SLP-76 via the adaptor protein ADAP. ADAP/SKAP1 then binds the Rap1-interacting protein, RIAM and contributes to TCR-induced inside-out LFA-1 activation and clustering by supporting formation of RAP1/RAPL complexes as well as membrane recruitment of these essential proteins involved in LFA-1 activation $(113,115,141,142)$. The SKAP1 $\mathrm{PH}$ domain was found to be required for membrane recruitment, and this in turn was necessary for the recruitment of RAPL to the membrane (114). A SKAP1 mutant that was constitutively associated with the membrane by addition of a myristoylation site disrupted the requirement for PI3K signalling in binding immobilised ICAM-1 suggesting that PI3K-mediated activation of LFA-1 is dependent on ADAP/SKAP1/RIAM signalling. Indeed, although RIAM contains a $\mathrm{PH}$ domain with high affinity for PtdIns monophosphates in vitro, SKAP1 is required for recruitment of Rap1/RIAM to the membrane during LFA-1 activation (142). In accordance, K152E mutation of SKAP1 eliminated $\mathrm{PIP}_{3}$-binding in vitro and as a result impaired immobilised ICAM-1-binding (143). Unexpectedly, this mutant did not abolish SKAP1/ADAP/RIAM/RAPL binding to the membrane, suggesting redundancy in the pathways resulting in membrane-recruitment of these proteins. Surprisingly, SKAP1 mutants lacking the $\mathrm{PH}$ domain do not significantly alter its role in integrin-mediated adhesion, suggesting the mechanism by which PI3K regulates SKAP1 is still incompletely understood $(113,143,144)$.

\section{KINDLIN3}

Mutations of the crucial LFA-1 regulator, KINDLIN-3, are the cause of leukocyte adhesion deficiency III (LAD-III), a rare autosomal disorder, resulting in severe bleeding and lifethreatening infections as a result of defective $\beta 1$ - and $\beta 2$ integrin-mediated adhesion $(145,146)$. Studies by Hart et al. suggest that KINDLIN-3 has higher affinity to $\mathrm{PIP}_{3}$ than $\mathrm{PIP}_{2}$ (147). They also found that the $\mathrm{PIP}_{3}$-binding was necessary for the function of KINDLIN-3, as KINDLIN-3 mutants that specifically did not bind $\mathrm{PIP}_{3}$ failed to rescue adhesion of LAD-III cells to ICAM-1. KINDLIN-3 was also found in structural studies to bind $\mathrm{PIP}^{3}$ with higher affinity than $\mathrm{PIP}_{2}$ (148) and the $\mathrm{PH}$ domain was found to regulate the translocation of KINDLIN-3 to the surface membrane in neutrophils (149). These studies therefore suggests that KINDLIN-3 is at least partially regulated by $\mathrm{PI} 3 \mathrm{~K}$, though this has yet to be confirmed in lymphocytes.

Thus, several studies indicate a key role for PI3K effector molecules in regulating integrin affinity/avidity, and multiple other proteins have been implicated in PI3K mediated integrin regulation indirectly (Figure $4 B$ ).

\section{Regulation of the RHO Family of GTPases}

The RHO family of GTPases, which include RAC, RhoA and CDC42 are both positively and negatively regulated by $\mathrm{PH}$ domain-containing GEFs and GAPs that have affinity for $\mathrm{PIP}_{3}$ and have been implicated in regulation of LFA-1. RhoA and RAC1 have been implicated in positively regulating LFA-1 avidity by controlling the affinity and clustering of LFA-1 (150, 151). By contrast, $\mathrm{CDC} 42$ and $\mathrm{RhoH}$ negatively regulate LFA-1 suggesting a complex integrated role of these proteins in LFA-1 regulation (119, 151). TEC kinases regulate cytoskeletal remodelling and LFA-1-mediated adhesion through activation of RHO-family proteins (152-154). In $\mathrm{T}$ cells the highest expressed TEC kinases are ITK and RLK, and Itk KO cells have decreased adhesion to ICAM-1 (154). RLK does not contain a PH domain, whereas ITK contains a $\mathrm{PH}$ domain that binds selectively to $\mathrm{PIP}_{3}$ (155), but the role of this in $\mathrm{T}$ cell integrin-mediated adhesion is unclear. Similar results have been described for the RHO GEF, VAV1 implicating it in clustering of LFA-1, but it is not known if this effect is PI3Kdependent although VAV1 can be regulated in part by PI3K (156-158). Similarly the RAC-GEF, P-REX1, which also contains a $\mathrm{PIP}_{3}$-binding $\mathrm{PH}$ domain, has been implicated in LFA-1 affinity and avidity regulation (159). It is likely that TEC kinases, VAV1, and P-REX1 are more important for LFA-1 clustering, and thereby increased avidity, than for affinity regulation as RHO family proteins are known to be important for cytoskeletal remodelling, and recruitment of proteins to the synapse (154). PI3K activity is not sufficient to activate all RHO family proteins (160) and has in some studies been shown to inhibit RAC activity in T cells (128), suggesting a complex interplay of this network of regulators in $\mathrm{RHO}$ regulation and downstream regulation of LFA-1.

Intriguingly, DOCK proteins which do not contain $\mathrm{PH}$ domains have been suggested to have affinity to $\mathrm{PIP}_{3}$ via socalled Dock Homology Domains (DHR1) (161). However, the extent of direct $\mathrm{PIP}_{3}$ affinity, and whether the affinity is a result of DOCK-proteins interacting with the $\mathrm{PH}$-domain-containing ELMO proteins is still debated $(91,162)$. DOCK2 was described earlier in the review in the context of chemokinestimulated LFA-1 activation but does not seem to affect TCRinduced LFA-1 activation, as it seems to be involved in TCRinduced RAC-dependent TCR clustering, without affecting LFA-1 translocation to the IS $(91,163)$. However, it is possible that this is context-specific, and some subsets thus might be more or less dependent on DOCK2 for efficient LFA-1 activation.

\section{Additional PH-Domain Containing Regulators of LFA-1}

DNM2 which is known for its role in regulating vesicular traffic, has been suggested to also regulate integrin affinity directly via FAK/PYK2- and C3G-mediated RAP1 activation (164). DNM2 has a $\mathrm{PH}$ domain, however it does not appear to have affinity for $\mathrm{PIP}_{3}$ in screens of $\mathrm{PIP}_{3}$-binding $(165,166)$, and it is therefore unlikely that it is regulated by $\mathrm{PI} 3 \mathrm{~K}$.

Interestingly, some RAP GTPase activating proteins (GAPs) have PH domains, including the GAP1-family members RASA3 and RASAL (167-169). In platelets, RASA3 inhibits the affinity of the integrin $\alpha \mathrm{IIb} \beta 3$ in a $\mathrm{PIP}_{3}$-dependent manner (169). How the function of $\mathrm{PIP}_{3}$-dependent inhibitors of integrins is 
coordinated with $\mathrm{PH}$-domain containing proteins that activate integrins is an area of active investigation.

The fact that such a high proportion of LFA-1 regulators contain $\mathrm{PH}$ domains suggests key roles for PI3K-mediated signalling in regulating LFA-1, though these may be cell, receptor, and context dependent. Multiple possible mechanisms of PI3K-mediated regulation are plausible; firstly, it is possible that PI3K activity directly activates the $\mathrm{PIP}_{3}$-binding LFA-1 regulators by inducing a conformational change in the proteins as is suggested for KINDLIN3 (147). Secondly, $\mathrm{PIP}_{3}$ could colocalise proteins that interact and activate each other (As observed during activation of AKT by PDK1). Thirdly, it is possible that microclusters of $\mathrm{PIP}_{3}$ colocalise with LFA-1 spatiotemporally during LFA-1 activation. Similarly, it is possible that $\mathrm{PIP}_{3}$ inactivates negative regulators of LFA-1 as has been suggested for RASA3-mediated regulation of platelet integrins (169) by similar mechanisms, i.e. conformational inactivation, colocalization of negative regulators with other proteins that inhibit them, or by sequestering the negative regulators from LFA-1 during activation.

\section{PI3K-MEDIATED REGULATION OF NAÏVE T CELL MIGRATION AND HOMEOSTASIS}

The expression of homing molecules CD62L and CCR7 on the surface of naïve $\mathrm{T}$ cells is critical for orchestrating naïve $\mathrm{T}$ cell trafficking to LNs, where these cells may become activated following antigen encounter and differentiate into effector cells. The maintenance of CD62L and CCR7 expression on naïve T cells is regulated by $\mathrm{PI} 3 \mathrm{~K} \delta$ signalling and transcription factors of the Forkhead Box protein family, with FOXO1 being a particularly important player. FOXO1 is inhibited by AKT downstream of PI3K (Figure 5) (170-172). Once phosphorylated by AKT, FOXO1 is excluded from the nucleus

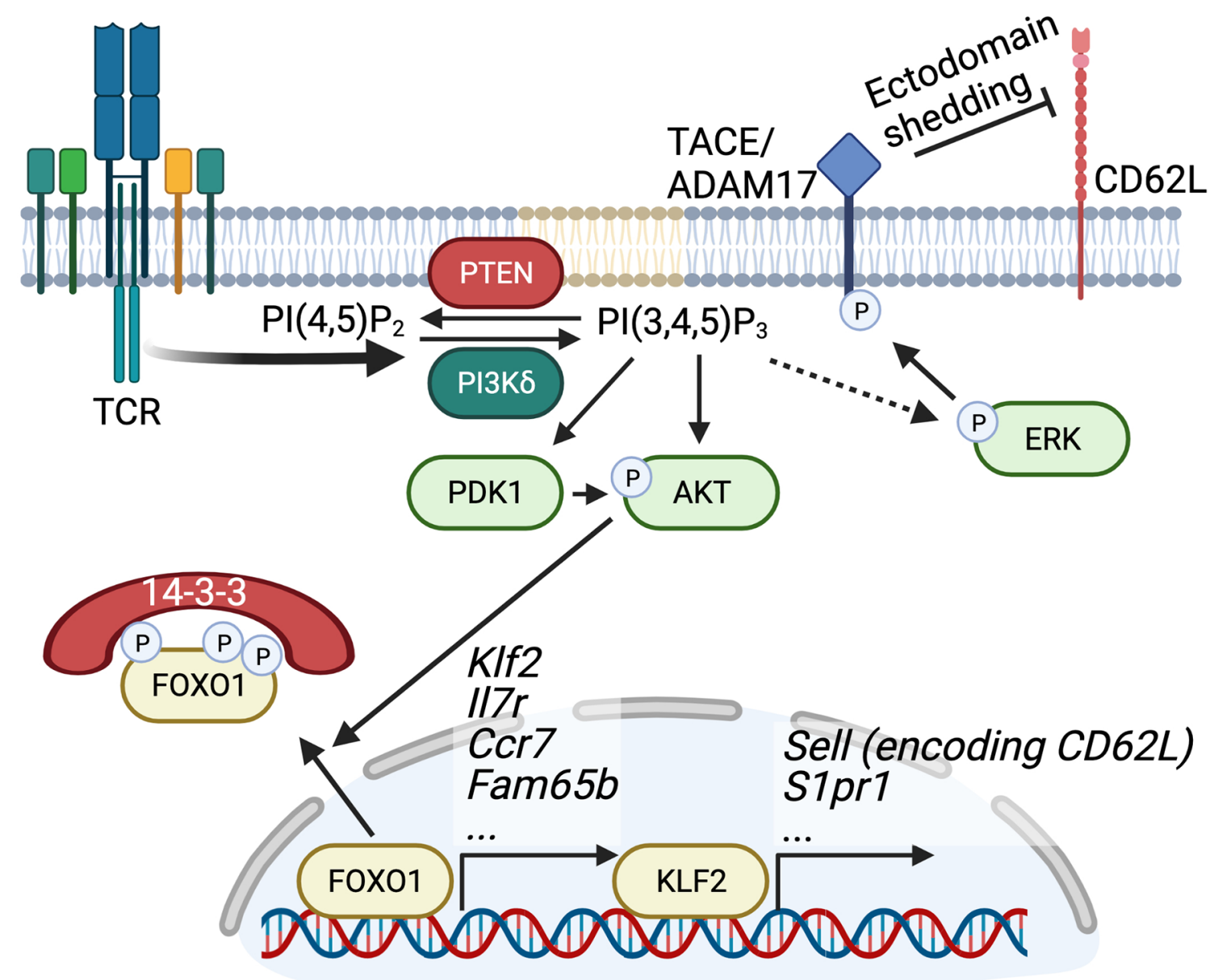

FIGURE 5 | PI3K 8 -mediated regulation of CD62L, CCR7, and S1PR1. PI3K-mediated PIP 3 production leads to recruitment of PDK1 and AKT, leading to AKT activation. AKT phosphorylates FOXO1, which allows for binding of the 14-3-3 leading to cytosolic sequestration of FOXO1. FOXO1 promotes transcription of KIf2 (as well as $/ 17 r$, CCr7, Fam65b). Decreased expression of the transcription factor KLF2 in turn results in decreased transcription of the CD62L encoding gene Sell and S1pr1. Figure made in BioRender. 
and targeted for degradation (173). Transcriptional activity of FOXO1 is high in naïve T cells and results in robust expression of CD62L and CCR7 through control of KLF2 levels, a transcription factor that drives expression of these key homing molecules (174). In addition, FOXO1 activity is required to maintain IL-7R $\alpha$ expression, a cytokine receptor key to maintenance of naïve $\mathrm{T}$ cell survival and homeostasis (175). Following $\mathrm{T}$ cell activation $\mathrm{PI} 3 \mathrm{~K} \delta$-mediated signals result in the phosphorylation and inactivation of FOXO1, resulting in a suppression of important FOXO1 and KLF2 target genes involved in regulating migration such as CD62L, CCR7, Fam65b, and others (176-179) (Figure 5). As a result of this loss of homing molecule expression, activated $\mathrm{T}$ cells are diverted away from entering LNs and instead are biased towards migration into peripheral tissues where they can perform their effector function. In addition to CD62L and CCR7 downregulation, the KLF2 target S1PR1 is also downregulated downstream of PI3K $\delta$ mediated FOXO1 inhibition $(178,180)$. Downregulation of S1PR1 expression results in a loss of T cell egress capacity and, combined with negative regulation of CD62L and CCR7 expression, limits the recirculation of activated $\mathrm{T}$ cells (Figure 5). In fact, suppression of S1PR1 expression is particularly important for the establishment of tissue resident memory $\mathrm{T}$ cells $\left(\mathrm{T}_{\mathrm{RM}}\right)$, which reside long term at barrier sites and are potent inducers of cell-mediated immunity (181). Therefore, $\mathrm{PI} 3 \mathrm{~K} \delta$ signals are instrumental in coordinating the acquisition of effector function with necessary changes in cell mobility that are required to execute functional immune responses (Figure 5).

Further regulation of CD62L expression on the surface of $\mathrm{T}$ cells is mediated through proteolytic cleavage of the ectodomain of CD62L by a process known as CD62L shedding. Following TCR activation, phosphorylation of TNF converting enzyme (TACE)/disintegrin and metalloprotease 17 (ADAM17) drives the trafficking of this protease to the cell surface, facilitating its cleavage of the ectodomain of CD62L (182-184). T cells expressing kinase dead $\mathrm{p} 110 \delta^{\mathrm{D} 910 \mathrm{~A}}$ show impaired shedding of CD62L from the cell surface, suggesting that $\mathrm{PI} 3 \mathrm{~K} \delta$ activity is critical in this process (185). Mechanistically, it has been shown that phosphorylation of TACE/ADAM17 by mitogen activated protein kinase (MAPK) ERK1/2 is required for the ability of this protease to cleave cell surface molecules like CD62L (186-188) and ERK phosphorylation is impaired in PI $3 \mathrm{~K} \delta$-deficient T cells (Figure 5) $(185,189)$.

\section{CCR7 Expression, CD62L-Shedding and LFA-1 Activation - Three Birds, One Stone?}

It is intriguing that $\mathrm{PI} 3 \mathrm{~K}$ signalling regulates multiple processes involved in T cell migration. PI3K-mediated CD62L-shedding and reduced CD62L, S1P1, and CCR7 expression results in decreased LN entry and is an important step in $\mathrm{T}$ cell differentiation to effector subsets. Concurrently, as PI3Ksignaling increases integrin affinity, PI3K signals can regulate migration and adhesion, including transendothelial migration into LNs. Consequently, inhibition of PI3K or disruption of PI3K signalling will affect all of these rheostats of migration, but not always in predictable ways. Hence, PTEN-deficient T cells with high $\mathrm{PIP}_{3}$ levels are excluded from LNs after adoptive transfer (190). Nevertheless, APDS patients suffer from lymphadenopathy and this is revered upon treatment with a $\mathrm{PI} 3 \mathrm{~K} \delta$ inhibitor (36).

Studies of migration of PI3K-deficient T cells as well as use of inhibitors in mice provide some indication of how inhibition affects $\mathrm{T}$ cell distribution in vivo. p110 $\gamma$-deficient $\mathrm{T}$ cells show reduced migration towards chemokines, whereas p $110 \delta$ deficient T cells respond to chemokines similarly to WT cells (191). Similarly, p110 $\gamma$ selective inhibitors affect responses to chemokines, whereas $\mathrm{p} 110 \alpha / \beta / \delta$ selective inhibitors do not affect responses to chemokines, except for at very high concentrations, likely as a result of off-target effects (192). Following LN entry, p110 $\gamma$-deficient $\mathrm{T}$ cells seem to migrate interstitially similarly to WT T cells, and chemokine-induced interstitial migration seems independent of PI3K signalling (193). However, treatment with Wortmannin as well as disruption of regulatory p85 subunits of class IA PI3K showed that these cells migrated at lower velocities than WT cells, although T cell location within the LN did not seem altered (194). PI3K $\delta$ under steady state does not contribute to $\mathrm{T}$ cell migration or chemokine-dependent migration per se, as p1 $10 \delta^{\mathrm{D} 910 \mathrm{~A}} \mathrm{~T}$ cells migrated like WT T cells in endothelial cellcoated transwell assays as well as following adoptive transfer (195). However, following antigenic challenge, p110 $\delta$ was required for efficient migration to the site of inflammation and presence of antigen, consistent with a key role for $\mathrm{PI} 3 \mathrm{~K} \delta$ in regulating integrin affinity (195). Disruption of $\mathrm{p} 110 \delta$ results in increased track velocities of OT-II CD $4^{+} \mathrm{T}$ cells in $\mathrm{LN}$ slices with OVA-pulsed DCs, as a result of decreased interaction times with the peptide-presenting DCs in the slices (128). Similar results have been observed for $110 \gamma$-deficient $\mathrm{T}$ cells that are defective for antigen-dependent and chemokine-dependent migration of effector $\mathrm{CD}^{+}$and $\mathrm{CD}^{+} \mathrm{T}$ cells $(196,197)$. Interestingly, CD28 seems to also be important for homing of antigen-stimulated $\mathrm{T}$ cells to non-lymphoid tissues, whereas CD28 (Y173F) that is uncoupled from PI3K $\delta$ was defective. This suggests that CD28mediated activation of PI3K is involved in migration of activated $\mathrm{T}$ cells to non-lymphoid sites (198). Consequently, when inhibiting PI3K $\delta$, homeostatic migration of naïve $\mathrm{T}$ cells $\left(\mathrm{T}_{\mathrm{N}}\right)$ seems unperturbed (as these have low PI3K activity in the first place), whereas activated $\mathrm{T}$ cells show decreased antigendependent migration into non-lymphoid tissues.

Central memory $\mathrm{T}$ cells $\left(\mathrm{T}_{\mathrm{CM}}\right)$ that are $\mathrm{CD}_{2} \mathrm{~L}^{+} \mathrm{CCR} 7^{+} \mathrm{LFA}-1^{+}$ are consequently supported by $\mathrm{PI} 3 \mathrm{~K} \delta$ inhibition, whereas effector $\mathrm{T}$ cells ( $\mathrm{T}_{\mathrm{eff}}$ ) and effector memory $\mathrm{T}$ cells $\left(\mathrm{T}_{\mathrm{EM}}\right)$ (CD62L'CCR7'LFA$1^{+}$) are inhibited (Figure 6A). This is largely supported by the fact that APDS patients have reduced $\mathrm{T}_{\mathrm{CM}}$ cells, and increased $\mathrm{T}_{\text {eff }}$ cells (32), whereas $\mathrm{p} 110 \delta^{\mathrm{D} 910 \mathrm{~A}}$ mice have normal memory $\mathrm{T}$ cells, but reduced $\mathrm{T}_{\text {eff }}$ cells (22) (Figure 6B). These PI3K-dependent alterations of $\mathrm{T}$ cell memory responses are possibly affected by altered expression of migratory receptors, however, differentiation of $\mathrm{p} 110 \delta^{\mathrm{D} 910 \mathrm{~A}} \mathrm{~T}$ cells to $\mathrm{T}_{\text {eff }}$ is largely defective, implicating PI3K more broadly in differentiation and migration. 
A

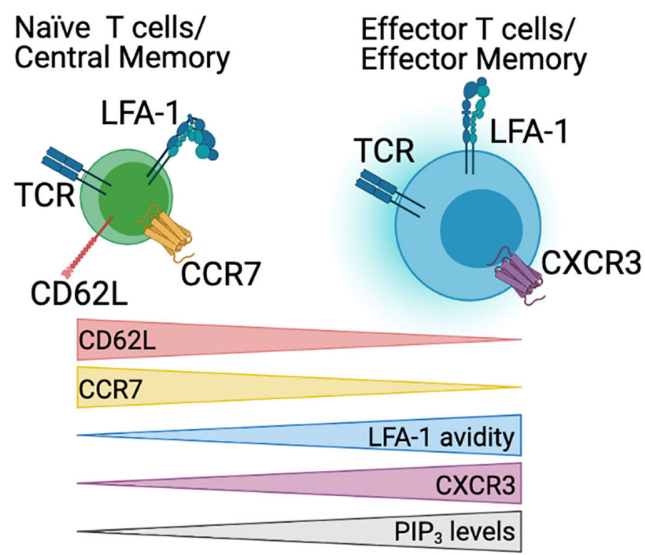

B

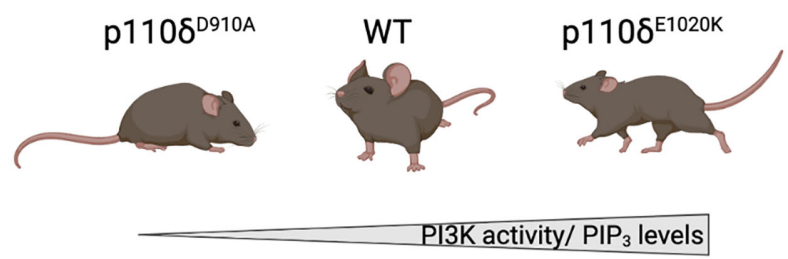

$\mathrm{T}_{\mathrm{N}} / \mathrm{T}_{\mathrm{CM}}$ cells

FIGURE 6 | Involvement of PI3K signalling in T cell migration. (A) Diagram of relative surface levels of CD62L, CCR7, CXCR3, and avidity of LFA-1 in naïve T cells $\left(T_{N}\right) /$ Central memory $T$ cells $\left(T_{C M}\right)$ and effector $T$ cells $\left(T_{\text {eff }}\right)$ /effector memory $T$ cells $\left(T_{E M}\right)$. (B) Spectrum of PI3K activity in PI3K mutant mouse models, and how this affects the levels of $T_{N} / T_{C M}$ and $T_{\text {eff }} / T_{E M}$ cells. Figure made in BioRender.

\section{PI3K INHIBITORS - A THERAPEUTIC PERSPECTIVE}

Because of the important role of PI3K signalling in antigendependent migration, $\mathrm{PI} 3 \mathrm{~K} \delta$ is a promising target for therapies, where broad blockade of $\mathrm{T}_{\text {eff }}$ and $\mathrm{T}_{\mathrm{EM}}$ migration is favourable. There is a growing body of evidence that alloreactive memory cells are responsible for allograft rejection Reviewed in (199). Treatments have focused on blocking costimulatory pathways in $\mathrm{T}$ cells, but some patients are resistant to these treatments. LFA-1 and/or VLA-4 blocking antibodies (i.e. Efalizumab or Natalizumab) have been used in these patients with some success as these antibodies reduce the migration and activation of memory subsets. However, some anti-LFA-1 or anti-VLA-4treated patients developed EBV-induced lymphoproliferative disease (200) or the fatal viral brain infection, progressive multifocal leukoencephalopathy (PML) (201), and it has been suggested that targeting TCR-induced inside-out signalling instead of broadly targeting both chemokine, and TCRinduced LFA-1 activation would restrict the blocking to antigen-induced migration of $\mathrm{T}$ cells, and therefore potentially limit the risk of PML or EBV-induced lymphoproliferation (202). As PI3K $\delta$ inhibition reduces the antigen-dependent migration of $\mathrm{T}$ cells by limiting CD62L and CCR7 downregulation, as well as LFA-1 activity, it is likely that PI3K $\delta$ inhibition would show efficacy in some types of allograft rejection. Indeed, PI $3 \mathrm{~K} \delta$ inhibition decreased chronic rejection of heart allografts in the absence of immunosuppressive treatment by interfering with antigen-dependent migration to the allograft (203). Other groups have also described data supporting the use of $\mathrm{PI} 3 \mathrm{~K} \delta$ inhibition in treatment of allograft rejection; both in mice with dual PI3K/mTOR inhibition (204) and with $\mathrm{p} 110 \alpha / \gamma(205)$ or $\mathrm{p} 110 \delta$ inhibition alone (206). However, it has been suggested that p110 $\gamma$ deletion is more effective than $\mathrm{p} 110 \delta$ deletion, and $\mathrm{p} 110 \delta$ deletion and inhibition even seemed to increase allograft rejection (207). Rag $\mathrm{KO}$ mice reconstituted with p110 $\delta$-deficient CD25- $\mathrm{T}$ cells (nonTregs) prolonged allograft acceptance compared to WTs. This suggests that the negative effect of PI $3 K \delta$ inhibition is due to blockade of the immunosuppressive properties of Tregs (207). Further studies will have to evaluate and determine the contribution of CD62L, CCR7 and LFA-1 affinity in allograft rejection, and it will be of interest to systematically determine under what conditions $\mathrm{p} 110 \delta$ or $\mathrm{p} 110 \gamma$ inhibition show efficacy.

Another treatment where $\mathrm{T}_{\mathrm{CM}}$ cells are favourable to $\mathrm{T}_{\text {eff }}$ cells, is during adoptive $\mathrm{T}$ cell transfer. Studies from Restifo et al. have indicated that adoptively transferred $\mathrm{T}_{\mathrm{CM}}$ cells are superior to transferred $\mathrm{T}_{\text {eff }}$ cells both in mice and primates (208-211). The reason why $\mathrm{T}_{\mathrm{CM}}$ cells elicit a better anti-tumour response is thought to be a result of their circulation to LNs where they persist for longer than short-lived $\mathrm{T}_{\text {eff }}$ cells (212). Thus, one of the major hallmarks of adoptive cell transfer has been to find ways of differentiating and expanding $\mathrm{T}$ cells without terminally differentiating the cells to $\mathrm{T}_{\text {eff }}$ cells. Multiple ways have been described that support a favourable differentiation profile; Expanding T cells in presence of IL-15, which supports a more central memory-like phenotype, also promotes anti-tumour immunity (213). Similarly, stimulation of WNT signalling (214), inhibition of glycolytic metabolism (215), as well as tethered IL-15 (216), promoted favourable central memory-like phenotypes that augmented anti-tumour immunity. PI3K/AKT inhibition has been shown to favour generation of cells with increased anti-tumour efficacy. AKT inhibition post transfer was shown to promote expansion of favourable $\mathrm{T}_{\mathrm{CM}}$ cells with improved in vivo efficacy $(217,218)$. Further, PI3K $\delta$ inhibition during expansion of $\mathrm{T}_{\mathrm{H}} 17$ cells followed by inhibition of $\beta$ catenin resulted in generation of $\mathrm{T}_{\mathrm{H}} 17$ cells that persisted in vivo and elicited heightened anti-tumour immunity (219). Similarly, 
PI3K $\delta$ inhibition with Idelalisib ex vivo before adoptive transfer heightened the anti-tumour response to an even greater extent than AKT inhibition (220). This suggests that PI3K-mediated anti-tumour efficacy in adoptive transfers is partially independent of AKT. Further, the transcription factor TCF7 was increased in the PI3K-inhibited ex vivo-expanded $\mathrm{T}$ cells, whereas it was not increased to the same extent following AKT inhibition (220). This is surprising as FOXO, which is inhibited by AKT, regulates expression of TCF7. It is possible that additional mechanisms downstream of $\mathrm{PI} 3 \mathrm{~K} \delta$ are responsible for the increased anti-tumour efficacy seen with PI3K $\delta$ inhibition, and further studies should evaluate the role of other mechanisms in this process, including decreased LFA-1 activation, or the role of other AKT-independent PI3K functions and effectors.

\section{SUMMARY}

In summary we have described how migration is regulated by PI3K signalling in $\mathrm{T}$ cells, with a focus on $\mathrm{T}$ cell integrin activation. As PI3K activity increases LFA-1 affinity, whilst decreasing CD62L surface levels and CCR7 expression,

\section{REFERENCES}

1. Davignon D, Martz E, Reynolds T, Kürzinger K, Springer TA. Lymphocyte Function-Associated Antigen 1 (LFA-1): A Surface Antigen Distinct From Lyt2,3 That Participates in T Lymphocyte-Mediated Killing. Proc Natl Acad Sci USA (1981) 78(7 I):4535-9. doi: 10.1073/pnas.78.7.4535

2. Davignon D, Martz E, Reynolds T, Kurzinger K, Springer TA. Monoclonal Antibody to a Novel Lymphocyte Function-Associated Antigen (LFA-1): Mechanism of Blockade of T Lymphocyte-Mediated Killing and Effects on Other T and B Lymphocyte Functions. J Immunol (1981) 127(2):590-5.

3. Kurzinger K, Reynolds T, Germain RN, Davignon D, Martz E, Springer TA. A Novel Lymphocyte Function-Associated Antigen (LFA-1): Cellular Distribution, Quantitative Expression, and Structure. J Immunol (1981) 127 (2):596-602.

4. Ley K, Kansas GS. Selectins in T-Cell Recruitment to Non-Lymphoid Tissues and Sites of Inflammation. Nat Rev Immunol (2004) 4(5):325-36. doi: 10.1038/ nri1351

5. Okkenhaug K. Signaling by the Phosphoinositide 3-Kinase Family in Immune Cells. Annu Rev Immunol (2013) 31:675-704. doi: 10.1146/annurev-immunol032712-095946

6. Bilanges B, Posor Y, Vanhaesebroeck B. PI3K Isoforms in Cell Signalling and Vesicle Trafficking. Nat Rev Mol Cell Biol (2019) 20(9):515-34. doi: 10.1038/ s41580-019-0129-Z

7. Songyang Z, Shoelson SE, Chaudhuri M, Gish G, Pawson T, Haser WG, et al. SH2 Domains Recognize Specific Phosphopeptide Sequences. Cell (1993) 72 (5):767-78. doi: 10.1016/0092-8674(93)90404-e

8. Roy NH, MacKay JL, Robertson TF, Hammer DA, Burkhardt JK. Crk Adaptor Proteins Mediate Actin-Dependent T Cell Migration and Mechanosensing Induced by the Integrin LFA-1. Sci Signaling (2018) 11(560):22-8. doi: 10.1126/ scisignal.aat 3178

9. Janas ML, Varano G, Gudmundsson K, Noda M, Nagasawa T, Turner M. Thymic Development Beyond Beta-Selection Requires Phosphatidylinositol 3Kinase Activation by CXCR4. J Exp Med (2010) 207(1):247-61. doi: 10.1084/ jem. 20091430

10. Ji H, Rintelen F, Waltzinger C, Bertschy Meier D, Bilancio A, Pearce W, et al. Inactivation of PI3Kgamma and PI3Kdelta Distorts T-Cell Development and signalling via $\mathrm{PI} 3 \mathrm{~K}$ is critical in the process of $\mathrm{T}$ cell migration following antigen stimulation. We further described how this potentially could be targeted in situations where a naïve/central memory-like phenotype is preferred to effector T cell subsets, such as in allograft rejections and adoptive $\mathrm{T}$ cell transfer.

\section{AUTHOR CONTRIBUTIONS}

$\mathrm{KHJ}$ conceived the ideas for the review, outlined, and wrote the manuscript. DPG and JHT contributed with intellectual support, and wrote sections of the manuscript. PLS contributed with intellectual support and suggestions for the manuscript. KO conceived the ideas for the review, wrote sections of the manuscript, and provided intellectual support. All authors contributed to the article and approved the submitted version.

\section{FUNDING}

This work was supported in part by funding from the intramural programs of NIAID and NHGRI, NIH and from the Wellcome Trust $[200925 / \mathrm{Z} / 16 / \mathrm{Z}]$.
Causes Multiple Organ Inflammation. Blood (2007) 110(8):2940-7. doi: 10.1182/blood-2007-04-086751

11. Webb LM, Vigorito E, Wymann MP, Hirsch E, Turner M. Cutting Edge: T Cell Development Requires the Combined Activities of the p110gamma and p110delta Catalytic Isoforms of Phosphatidylinositol 3-Kinase. J Immunol (2005) 175(5):2783-7. doi: 10.4049/jimmunol.175.5.2783

12. Trampont PC, Tosello-Trampont A-C, Shen Y, Duley AK, Sutherland AE, Bender TP, et al. CXCR4 Acts as a Costimulator During Thymic $\beta$-Selection. Nat Immunol (2010) 11(2):162-70. doi: 10.1038/ni.1830

13. Hagenbeek TJ, Naspetti M, Malergue F, Garcon F, Nunes JA, Cleutjens KB, et al. The Loss of PTEN Allows TCR Alphabeta Lineage Thymocytes to Bypass IL-7 and Pre-TCR-Mediated Signaling. J Exp Med (2004) 200(7):883-94. doi: 10.1084/jem.20040495

14. Suzuki A, Yamaguchi MT, Ohteki T, Sasaki T, Kaisho T, Kimura Y, et al. T CellSpecific Loss of Pten Leads to Defects in Central and Peripheral Tolerance. Immunity (2001) 14(5):523-34. doi: 10.1016/s1074-7613(01)00134-0

15. Patton DT, Garden OA, Pearce WP, Clough LE, Monk CR, Leung E, et al Cutting Edge: The Phosphoinositide 3-Kinase p110 Delta Is Critical for the Function of CD4+CD25+Foxp3+ Regulatory T Cells. J Immunol (2006) 177 (10):6598-602. doi: 10.4049/jimmunol.177.10.6598

16. Rolf J, Bell SE, Kovesdi D, Janas ML, Soond DR, Webb LM, et al. Phosphoinositide 3-Kinase Activity in T Cells Regulates the Magnitude of the Germinal Center Reaction. J Immunol (2010) 185(7):4042-52. doi: 10.4049/jimmunol.1001730

17. Gigoux M, Shang J, Pak Y, Xu M, Choe J, Mak TW, et al. Inducible Costimulator Promotes Helper T-Cell Differentiation Through Phosphoinositide 3-Kinase. Proc Natl Acad Sci USA (2009) 106(48):203716. doi: 10.1073/pnas.0911573106

18. Soond DR, Garcon F, Patton DT, Rolf J, Turner M, Scudamore C, et al. Pten Loss in CD4 T Cells Enhances Their Helper Function But Does Not Lead to Autoimmunity or Lymphoma. J Immunol (2012) 188(12):5935-43. doi: 10.4049/jimmunol.1102116

19. Soond DR, Bjorgo E, Moltu K, Dale VQ, Patton DT, Torgersen KM, et al. Pi3k p110delta Regulates T-Cell Cytokine Production During Primary and Secondary Immune Responses in Mice and Humans. Blood (2010) 115 (11):2203-13. doi: 10.1182/blood-2009-07-232330 
20. Okkenhaug K, Patton DT, Bilancio A, Garcon F, Rowan WC, Vanhaesebroeck B. The p110delta Isoform of Phosphoinositide 3-Kinase Controls Clonal Expansion and Differentiation of Th Cells. J Immunol (2006) 177(8):51228. doi: 10.4049/jimmunol.177.8.5122

21. Macintyre AN, Finlay D, Preston G, Sinclair LV, Waugh CM, Tamas P, et al. Protein Kinase B Controls Transcriptional Programs That Direct Cytotoxic T Cell Fate But Is Dispensable for T Cell Metabolism. Immunity (2011) 34 (2):224-36. doi: 10.1016/j.immuni.2011.01.012

22. Pearce VQ, Bouabe H, MacQueen AR, Carbonaro V, Okkenhaug K. Pi3kdelta Regulates the Magnitude of CD8+ T Cell Responses After Challenge With Listeria Monocytogenes. J Immunol (2015) 195(7):3206-17. doi: 10.4049/ jimmunol.1501227

23. Kurebayashi $Y$, Nagai S, Ikejiri A, Ohtani M, Ichiyama K, Baba Y, et al. Pi3kAkt-mTORC1-S6K1/2 Axis Controls Th17 Differentiation by Regulating Gfi1 Expression and Nuclear Translocation of Rorgamma. Cell Rep (2012) 1 (4):360-73. doi: 10.1016/j.celrep.2012.02.007

24. Nashed BF, Zhang T, Al-Alwan M, Srinivasan G, Halayko AJ, Okkenhaug K, et al. Role of the Phosphoinositide 3-Kinase p110delta in Generation of Type 2 Cytokine Responses and Allergic Airway Inflammation. Eur J Immunol (2007) 37(2):416-24. doi: 10.1002/eji.200636401

25. Haylock-Jacobs S, Comerford I, Bunting M, Kara E, Townley S, KlinglerHoffmann M, et al. PI3Kdelta Drives the Pathogenesis of Experimental Autoimmune Encephalomyelitis by Inhibiting Effector T Cell Apoptosis and Promoting Th17 Differentiation. J Autoimmun (2011) 36(3-4):278-87. doi: 10.1016/j.jaut.2011.02.006

26. Stark AK, Davenport ECM, Patton DT, Scudamore CL, Vanhaesebroeck B, Veldhoen M, et al. Loss of Phosphatidylinositol 3-Kinase Activity in Regulatory T Cells Leads to Neuronal Inflammation. J Immunol (2020) 205 (1):78-89. doi: 10.4049/jimmunol.2000043

27. Cohen SB, Bainter W, Johnson JL, Lin TY, Wong JCY, Wallace JG, et al. Human Primary Immunodeficiency Caused by Expression of a Kinase-Dead p110delta Mutant. J Allergy Clin Immunol (2019) 143(2):797-9.e2. doi: 10.1016/j.jaci.2018.10.005

28. Conley ME, Dobbs AK, Quintana AM, Bosompem A, Wang YD, CoustanSmith E, et al. Agammaglobulinemia and Absent B Lineage Cells in a Patient Lacking the p85alpha Subunit of PI3K. J Exp Med (2012) 209(3):463-70. doi: $10.1084 /$ jem. 20112533

29. Sogkas G, Fedchenko M, Dhingra A, Jablonka A, Schmidt RE, Atschekzei F. Primary Immunodeficiency Disorder Caused by Phosphoinositide 3-Kinase Delta Deficiency. J Allergy Clin Immunol (2018) 142(5):1650-3.e2. doi: 10.1016/j.jaci.2018.06.039

30. Swan DJ, Aschenbrenner D, Lamb CA, Chakraborty K, Clark J, Pandey S, et al. Immunodeficiency, Autoimmune Thrombocytopenia and Enterocolitis Caused by Autosomal Recessive Deficiency of PIK3CD-Encoded Phosphoinositide 3-Kinase Delta. Haematologica (2019) 104(10):e483-6. doi: 10.3324/haematol.2018.208397

31. Angulo I, Vadas O, Garçon F, Banham-Hall E, Plagnol V, Leahy TR, et al. Phosphoinositide 3-Kinase $\delta$ Gene Mutation Predisposes to Respiratory Infection and Airway Damage. Sci (New York NY) (2013) 342(6160):86671. doi: $10.1126 /$ science. 1243292

32. Lucas CL, Kuehn HS, Zhao F, Niemela JE, Deenick EK, Palendira U, et al. Dominant-Activating Germline Mutations in the Gene Encoding the PI(3)K Catalytic Subunit P1108 Result in T Cell Senescence and Human Immunodeficiency. Nat Immunol (2014) 15(1):88-97. doi: 10.1038/ni.2771

33. Lucas CL, Zhang Y, Venida A, Wang Y, Hughes J, McElwee J, et al. Heterozygous Splice Mutation in PIK3R1 Causes Human Immunodeficiency With Lymphoproliferation Due to Dominant Activation of PI3K. J Exp Med (2014) 211(13):2537-47. doi: 10.1084/jem.20141759

34. Coulter TI, Chandra A, Bacon CM, Babar J, Curtis J, Screaton N, et al. Clinical Spectrum and Features of Activated Phosphoinositide 3-Kinase Delta Syndrome: A Large Patient Cohort Study. J Allergy Clin Immunol (2017) 139(2):597-606.e4. doi: 10.1016/j.jaci.2016.06.021

35. Deau MC, Heurtier L, Frange P, Suarez F, Bole-Feysot C, Nitschke P, et al. A Human Immunodeficiency Caused by Mutations in the PIK3R1 Gene. J Clin Invest (2014) 124(9):3923-8. doi: 10.1172/JCI75746

36. Rao VK, Webster S, Dalm V, Sediva A, van Hagen PM, Holland S, et al. Effective "Activated PI3Kdelta Syndrome"-Targeted Therapy With the
PI3Kdelta Inhibitor Leniolisib. Blood (2017) 130(21):2307-16. doi: 10.1182/ blood-2017-08-801191

37. Jia Y, Yang Q, Wang Y, Li W, Chen X, Xu T, et al. Hyperactive PI3Kdelta Predisposes Naive T Cells to Activation Via Aerobic Glycolysis Programs. Cell Mol Immunol (2020) 18:1783-97. doi: 10.1038/s41423-020-0379-x

38. Wray-Dutra MN, Al Qureshah F, Metzler G, Oukka M, James RG, Rawlings DJ. Activated PIK3CD Drives Innate B Cell Expansion Yet Limits B CellIntrinsic Immune Responses. J Exp Med (2018) 215(10):2485-96. doi: 10.1084/jem.20180617

39. Preite S, Cannons JL, Radtke AJ, Vujkovic-Cvijin I, Gomez-Rodriguez J, Volpi S, et al. Hyperactivated PI3Kdelta Promotes Self and Commensal Reactivity at the Expense of Optimal Humoral Immunity. Nat Immunol (2018) 19(9):9861000. doi: $10.1038 / \mathrm{s} 41590-018-0182-3$

40. Stark AK, Chandra A, Chakraborty K, Alam R, Carbonaro V, Clark J, et al. Pi3k $\delta$ Hyper-Activation Promotes Development of B Cells That Exacerbate Streptococcus Pneumoniae Infection in an Antibody-Independent Manner. Nat Commun (2018) 9(1):1-16. doi: 10.1038/s41467-018-05674-8

41. Avery DT, Kane A, Nguyen T, Lau A, Nguyen A, Lenthall H, et al. GermlineActivating Mutations in PIK3CD Compromise B Cell Development and Function. J Exp Med (2018) 215(8):2073-95. doi: 10.1084/jem.20180010

42. Lucas CL, Chandra A, Nejentsev S, Condliffe AM, Okkenhaug K. Pi3k $\delta$ and Primary Immunodeficiencies. Nat Rev Immunol (2016) 4(11):702-14. doi: $10.1038 /$ nri.2016.93

43. Tangye SG, Bier J, Lau A, Nguyen T, Uzel G, Deenick EK. Immune Dysregulation and Disease Pathogenesis Due to Activating Mutations in PIK3CD-The Goldilocks' Effect. J Clin Immunol (2019) 39(2):148-58. doi: 10.1007/s10875-019-00612-9

44. Vanhaesebroeck B, Perry MW, Brown JR, André F, Okkenhaug K. PI3K Inhibitors Are Finally Coming of Age. Nat Rev Drug Discov (2021). doi: 10.1038/s41573-021-00209-1

45. Furman RR, Sharman JP, Coutre SE, Cheson BD, Pagel JM, Hillmen P, et al. Idelalisib and Rituximab in Relapsed Chronic Lymphocytic Leukemia. N Engl J Med (2014) 370(11):997-1007. doi: 10.1056/NEJMoa1315226

46. Okkenhaug K, Burger JA. PI3K Signaling in Normal B Cells and Chronic Lymphocytic Leukemia (CLL). Curr Topics Microbiol Immunol (2015) 393:123-42. doi: 10.1007/82_2015_484

47. Coutré SE, Barrientos JC, Brown JR, De Vos S, Furman RR, Keating MJ, et al. Management of Adverse Events Associated With Idelalisib Treatment: Expert Panel Opinion. Leukemia Lymphoma (2015) 56(10):2779-86. doi: 10.3109/ 10428194.2015.1022770

48. Lampson BL, Kasar SN, Matos TR, Morgan EA, Rassenti L, Davids MS, et al. Idelalisib Given Front-Line for Treatment of Chronic Lymphocytic Leukemia Causes Frequent Immune-Mediated Hepatotoxicity. Blood (2016) 128 (2):195-203. doi: 10.1182/blood-2016-03-707133

49. Ali K, Soond DR, Piñeiro R, Hagemann T, Pearce W, Lim EL, et al. Inactivation of PI(3)K P110 Breaks Regulatory T-Cell-Mediated Immune Tolerance to Cancer. Nature (2014) 509(7505):407-11. doi: 10.1038/ nature 13444

50. Eschweiler S, Suastegui CR, King E, Chudley L, Thomas J, Ottensmeier C, et al. Immunomodulatory Effects of PI3K $\delta$ Inhibition in Solid Tumors Evaluation in a Randomized Phase II Trial. doi: 10.21203/rs.3.rs-337290/v1

51. Hogg N. T-Cell Integrins: More Than Just Sticking Points. J Cell Sci (2003) 116 (23):4695-705. doi: 10.1242/jcs.00876

52. Mair I, Zandee SEJ, Toor IS, Saul L, McPherson RC, Leech MD, et al. A Context-Dependent Role for Alphav Integrins in Regulatory $\mathrm{T}$ Cell Accumulation at Sites of Inflammation. Front Immunol (2018) 9:264. doi: 10.3389/fimmu.2018.00264

53. Ostermann G, Weber KSC, Zernecke A, Schröder A, Weber C. JAM-1 Is a Ligand of the $\beta 2$ Integrin LFA- 1 Involved in Transendothelial Migration of Leukocytes. Nat Immunol (2002) 3(2):151-8. doi: 10.1038/ni755

54. Marlin SD, Springer TA. Purified Intercellular Adhesion Molecule-1 (ICAM-1) Is a Ligand for Lymphocyte Function-Associated Antigen 1 (LFA-1). Cell (1987) 51(5):813-9. doi: 10.1016/0092-8674(87)90104-8

55. Walling BL, Kim M. LFA-1 in T Cell Migration and Differentiation. Front Immunol (2018) 9:952. doi: 10.3389/fimmu.2018.00952

56. Malek AM. Hemodynamic Shear Stress and Its Role in Atherosclerosis. JAMA (1999) 282(21):2035. doi: 10.1001/jama.282.21.2035 
57. Monneau Y, Arenzana-Seisdedos F, Lortat-Jacob H. The Sweet Spot: How GAGs Help Chemokines Guide Migrating Cells. J Leukocyte Biol (2016) 99 (6):935-53. doi: 10.1189/jlb.3mr0915-440r

58. Baekkevold ES, Yamanaka T, Palframan RT, Carlsen HS, Reinholt FP, von Andrian UH, et al. The CCR7 Ligand Elc (CCL19) Is Transcytosed in High Endothelial Venules and Mediates T Cell Recruitment. J Exp Med (2001) 193 (9):1105-12. doi: 10.1084/jem.193.9.1105

59. Forster R, Schubel A, Breitfeld D, Kremmer E, Renner-Muller I, Wolf E, et al. CCR7 Coordinates the Primary Immune Response by Establishing Functional Microenvironments in Secondary Lymphoid Organs. Cell (1999) 99(1):23-33. doi: 10.1016/s0092-8674(00)80059-8

60. Constantin G, Majeed M, Giagulli C, Piccio L, Kim JY, Butcher EC, et al. Chemokines Trigger Immediate Beta2 Integrin Affinity and Mobility Changes: Differential Regulation and Roles in Lymphocyte Arrest Under Flow. Immunity (2000) 13(6):759-69. doi: 10.1016/s1074-7613(00)00074-1

61. Warnock RA, Askari S, Butcher EC, von Andrian UH. Molecular Mechanisms of Lymphocyte Homing to Peripheral Lymph Nodes. J Exp Med (1998) 187 (2):205-16. doi: 10.1084/jem.187.2.205

62. Berlin-Rufenach C, Otto F, Mathies M, Westermann J, Owen MJ, Hamann A, et al. Lymphocyte Migration in Lymphocyte Function-Associated Antigen (LFA)-1-Deficient Mice. J Exp Med (1999) 189(9):1467-78. doi: 10.1084/ jem.189.9.1467

63. Andrew DP, Spellberg JP, Takimoto H, Schmits R, Mak TW, Zukowski MM. Transendothelial Migration and Trafficking of Leukocytes in LFA-1-Deficient Mice. Eur J Immunol (1998) 28(6):1959-69. doi: 10.1002/(SICI)1521-4141 (199806)28:06<1959::AID-IMMU1959>3.0.CO;2-4

64. Hamann A, Jablonski-Westrich D, Duijvestijn A, Butcher EC, Baisch H, Harder R, et al. Evidence for an Accessory Role of LFA-1 in Lymphocyte-High Endothelium Interaction During Homing. J Immunol (1988) 140(3):693-9.

65. von Andrian UH, Mempel TR. Homing and Cellular Traffic in Lymph Nodes. Nat Rev Immunol (2003) 3(11):867-78. doi: 10.1038/nri1222

66. Sun H, Liu J, Zheng Y, Pan Y, Zhang K, Chen J. Distinct Chemokine Signaling Regulates Integrin Ligand Specificity to Dictate Tissue-Specific Lymphocyte Homing. Dev Cell (2014) 30(1):61-70. doi: 10.1016/j.devcel.2014.05.002

67. Reichardt P, Patzak I, Jones K, Etemire E, Gunzer M, Hogg N. A Role for LFA-1 in Delaying T-Lymphocyte Egress From Lymph Nodes. EMBO J (2013) 32 (6):829-43. doi: 10.1038/emboj.2013.33

68. Woolf E, Grigorova I, Sagiv A, Grabovsky V, Feigelson SW, Shulman Z, et al. Lymph Node Chemokines Promote Sustained T Lymphocyte Motility Without Triggering Stable Integrin Adhesiveness in the Absence of Shear Forces. Nat Immunol (2007) 8(10):1076-85. doi: 10.1038/ni1499

69. Lammermann T, Bader BL, Monkley SJ, Worbs T, Wedlich-Soldner R, Hirsch $\mathrm{K}$, et al. Rapid Leukocyte Migration by Integrin-Independent Flowing and Squeezing. Nature (2008) 453(7191):51-5. doi: 10.1038/nature06887

70. Cyster JG, Schwab SR. Sphingosine-1-Phosphate and Lymphocyte Egress From Lymphoid Organs. Annu Rev Immunol (2012) 30:69-94. doi: 10.1146/ annurev-immunol-020711-075011

71. Arasa J, Collado-Diaz V, Kritikos I, Medina-Sanchez JD, Friess MC, Sigmund EC, et al. Upregulation of VCAM-1 in Lymphatic Collectors Supports Dendritic Cell Entry and Rapid Migration to Lymph Nodes in Inflammation. J Exp Med (2021) 218(7):e20201413. doi: 10.1084/jem. 20201413

72. Brinkman CC, Iwami D, Hritzo MK, Xiong Y, Ahmad S, Simon T, et al. Treg Engage Lymphotoxin Beta Receptor for Afferent Lymphatic Transendothelial Migration. Nat Commun (2016) 7(1):12021. doi: 10.1038/ncomms12021

73. Teijeira A, Hunter MC, Russo E, Proulx ST, Frei T, Debes GF, et al. T Cell Migration From Inflamed Skin to Draining Lymph Nodes Requires Intralymphatic Crawling Supported by ICAM-1/LFA-1 Interactions. Cell Rep (2017) 18(4):857-65. doi: 10.1016/j.celrep.2016.12.078

74. Overstreet MG, Gaylo A, Angermann BR, Hughson A, Hyun Y-M, Lambert $\mathrm{K}$, et al. Inflammation-Induced Interstitial Migration of Effector CD4+ T Cells Is Dependent on Integrin $\alpha v$. Nat Immunol (2013) 14(9):949-58. doi: 10.1038/ ni. 2682

75. Luster $\mathrm{AD}$, Alon R, Von Andrian UH. Immune Cell Migration in Inflammation: Present and Future Therapeutic Targets. Nat Immunol (2005) 6(12):1182-90. doi: 10.1038/ni1275

76. Nourshargh S, Alon R. Leukocyte Migration Into Inflamed Tissues. Immunity (2014) 41(5):694-707. doi: 10.1016/j.immuni.2014.10.008
77. Smith-Garvin JE, Koretzky GA, Jordan MS. T Cell Activation. Annu Rev Immunol (2009) 27(1):591-619. doi: 10.1146/annurev.immunol.021908. 132706

78. Mastrogiovanni M, Juzans M, Alcover A, Di Bartolo V. Coordinating Cytoskeleton and Molecular Traffic in T Cell Migration, Activation, and Effector Functions. Front Cell Dev Biol (2020) 8:591348. doi: 10.3389/ fcell.2020.591348

79. Finetti F, Baldari CT. The Immunological Synapse as a Pharmacological Target. Pharmacol Res (2018) 134:118-33. doi: 10.1016/j.phrs.2018.06.009

80. Contento RL, Campello S, Trovato AE, Magrini E, Anselmi F, Viola A. Adhesion Shapes T Cells for Prompt and Sustained T-Cell Receptor Signalling. EMBO J (2010) 29(23):4035-47. doi: 10.1038/emboj.2010.258

81. Lee KH, Holdorf AD, Dustin ML, Chan AC, Allen PM, Shaw AS. T Cell Receptor Signaling Precedes Immunological Synapse Formation. Science (2002) 295(5559):1539-42. doi: 10.1126/science.1067710

82. Grakoui A, Bromley SK, Sumen C, Davis MM, Shaw AS, Allen PM, et al. The Immunological Synapse: A Molecular Machine Controlling T Cell Activation. Science (1999) 285(5425):221-7. doi: 10.1126/science.285.5425.221

83. Monks CR, Freiberg BA, Kupfer H, Sciaky N, Kupfer A. Three-Dimensional Segregation of Supramolecular Activation Clusters in T Cells. Nature (1998) 395(6697):82-6. doi: 10.1038/25764

84. Graf B, Bushnell T, Miller J. LFA-1-Mediated T Cell Costimulation Through Increased Localization of TCR/Class II Complexes to the Central Supramolecular Activation Cluster and Exclusion of CD45 From the Immunological Synapse. J Immunol (2007) 179(3):1616-24. doi: 10.4049/ jimmunol.179.3.1616

85. Varma R, Campi G, Yokosuka T, Saito T, Dustin ML. T Cell ReceptorProximal Signals Are Sustained in Peripheral Microclusters and Terminated in the Central Supramolecular Activation Cluster. Immunity (2006) 25 (1):117-27. doi: 10.1016/j.immuni.2006.04.010

86. Nguyen K, Sylvain NR, Bunnell SC. T Cell Costimulation Via the Integrin VLA-4 Inhibits the Actin-Dependent Centralization of Signaling Microclusters Containing the Adaptor SLP-76. Immunity (2008) 28(6):81021. doi: 10.1016/j.immuni.2008.04.019

87. Mossman KD, Campi G, Groves JT, Dustin ML. Altered TCR Signaling From Geometrically Repatterned Immunological Synapses. Science (2005) 310 (5751):1191-3. doi: 10.1126/science.1119238

88. Garcon F, Patton DT, Emery JL, Hirsch E, Rottapel R, Sasaki T, et al. CD28 Provides T-Cell Costimulation and Enhances PI3K Activity at the Immune Synapse Independently of Its Capacity to Interact With the p85/p110 Heterodimer. Blood (2008) 111(3):1464-71. doi: 10.1182/blood-2007-08108050

89. Huppa JB, Gleimer M, Sumen C, Davis MM. Continuous T Cell Receptor Signaling Required for Synapse Maintenance and Full Effector Potential. Nat Immunol (2003) 4(8):749-55. doi: 10.1038/ni951

90. Costello PS, Gallagher M, Cantrell DA. Sustained and Dynamic Inositol Lipid Metabolism Inside and Outside the Immunological Synapse. Nat Immunol (2002) 3(11):1082-9. doi: 10.1038/ni848

91. Le Floc'h A, Tanaka Y, Bantilan NS, Voisinne G, Altan-Bonnet G, Fukui Y, et al. Annular PIP3 Accumulation Controls Actin Architecture and Modulates Cytotoxicity at the Immunological Synapse. J Exp Med (2013) 210(12):272137. doi: 10.1084 /jem.20131324

92. Gawden-Bone CM, Frazer GL, Richard AC, Ma CY, Strege K, Griffiths GM. Pip5 Kinases Regulate Membrane Phosphoinositide and Actin Composition for Targeted Granule Secretion by Cytotoxic Lymphocytes. Immunity (2018) 49(3):427-37.e4. doi: 10.1016/j.immuni.2018.08.017

93. Ritter AT, Kapnick SM, Murugesan S, Schwartzberg PL, Griffiths GM, Lippincott-Schwartz J. Cortical Actin Recovery at the Immunological Synapse Leads to Termination of Lytic Granule Secretion in Cytotoxic T Lymphocytes. Proc Natl Acad Sci (2017) 114(32):E6585-94. doi: 10.1073/ pnas. 1710751114

94. Basu R, Whitlock BM, Husson J, Le Floc'h A, Jin W, Oyler-Yaniv A, et al. Cytotoxic T Cells Use Mechanical Force to Potentiate Target Cell Killing. Cell (2016) 165(1):100-10. doi: 10.1016/j.cell.2016.01.021

95. Letschka T, Kollmann V, Pfeifhofer-Obermair C, Lutz-Nicoladoni C, Obermair GJ, Fresser F, et al. PKC-Theta Selectively Controls the Adhesion-Stimulating Molecule Rap1. Blood (2008) 112(12):4617-27. doi: 10.1182/blood-2007-11-121111 
96. Ghandour H, Cullere X, Alvarez A, Luscinskas FW, Mayadas TN. Essential Role for Rap1 Gtpase and Its Guanine Exchange Factor CalDAG-GEFI in LFA-1 But Not VLA-4 Integrin-Mediated Human T-Cell Adhesion. Blood (2007) 110(10):3682-90. doi: 10.1182/blood-2007-03-077628

97. Burbach BJ, Medeiros RB, Mueller KL, Shimizu Y. T-Cell Receptor Signaling to Integrins. Immunol Rev (2007) 218(1):65-81. doi: 10.1111/j.1600065X.2007.00527.x

98. Nolz JC, Nacusi LP, Segovis CM, Medeiros RB, Mitchell JS, Shimizu Y, et al. The WAVE2 Complex Regulates T Cell Receptor Signaling to Integrins Via Abl- and CrkL-C3G-Mediated Activation of Rap1. J Cell Biol (2008) 182 (6):1231-44. doi: 10.1083/jcb.200801121

99. Katagiri K, Hattori M, Minato N, S-k I, Takatsu K, Kinashi T. Rap1 Is a Potent Activation Signal for Leukocyte Function-Associated Antigen 1 Distinct From Protein Kinase C and Phosphatidylinositol-3-OH Kinase. Mol Cell Biol (2000) 20(6):1956-69. doi: 10.1128/MCB.20.6.1956-1969.2000

100. Katagiri K, Maeda A, Shimonaka M, Kinashi T. RAPL, a Rap1-binding Molecule That Mediates Rap1-Induced Adhesion Through Spatial Regulation of LFA-1. Nat Immunol (2003) 4(8):741-8. doi: 10.1038/ni950

101. Kinashi T. Intracellular Signalling Controlling Integrin Activation in Lymphocytes. Nat Rev Immunol (2005) 5(7):546-59. doi: 10.1038/nri1646

102. Sebzda E, Bracke M, Tugal T, Hogg N, Cantrell DA. Rap1A Positively Regulates $\mathrm{T}$ Cells Via Integrin Activation Rather Than Inhibiting Lymphocyte Signaling. Nat Immunol (2002) 3(3):251-8. doi: 10.1038/ni765

103. Shimonaka M, Katagiri K, Nakayama T, Fujita N, Tsuruo T, Yoshie O, et al. Rap1 Translates Chemokine Signals to Integrin Activation, Cell Polarization, and Motility Across Vascular Endothelium Under Flow. J Cell Biol (2003) 161(2):417-27. doi: 10.1083/jcb.200301133

104. Li Z, Jiang H, Xie W, Zhang Z, Smrcka AV, Wu D. Roles of PLC-Beta2 and -Beta3 and PI3Kgamma in Chemoattractant-Mediated Signal Transduction. Science (2000) 287(5455):1046-9. doi: 10.1126/science.287.5455.1046

105. Balla T. Putting G Protein-Coupled Receptor-Mediated Activation of Phospholipase C in the Limelight. J Gen Physiol (2010) 135(2):77-80. doi: 10.1085/jgp.200910396

106. Ganju RK, Brubaker SA, Meyer J, Dutt P, Yang Y, Qin S, et al. The AlphaChemokine, Stromal Cell-Derived Factor-1alpha, Binds to the Transmembrane G-Protein-Coupled CXCR-4 Receptor and Activates Multiple Signal Transduction Pathways. J Biol Chem (1998) 273 (36):23169-75. doi: 10.1074/jbc.273.36.23169

107. Lafuente EM, van Puijenbroek AA, Krause M, Carman CV, Freeman GJ, Berezovskaya A, et al. RIAM, an Ena/VASP and Profilin Ligand, Interacts With Rap1-GTP and Mediates Rap1-induced Adhesion. Dev Cell (2004) 7 (4):585-95. doi: 10.1016/j.devcel.2004.07.021

108. Lee HS, Lim CJ, Puzon-McLaughlin W, Shattil SJ, Ginsberg MH. RIAM Activates Integrins by Linking Talin to Ras GTPase Membrane-Targeting Sequences. J Biol Chem (2009) 284(8):5119-27. doi: 10.1074/jbc. M807117200

109. Yang J, Zhu L, Zhang H, Hirbawi J, Fukuda K, Dwivedi P, et al. Conformational Activation of Talin by RIAM Triggers Integrin-Mediated Cell Adhesion. Nat Commun (2014) 5:5880. doi: 10.1038/ncomms6880

110. Tadokoro S, Shattil SJ, Eto K, Tai V, Liddington RC, de Pereda JM, et al. Talin Binding to Integrin Beta Tails: A Final Common Step in Integrin Activation. Science (2003) 302(5642):103-6. doi: 10.1126/science.1086652

111. Wegener KL, Partridge AW, Han J, Pickford AR, Liddington RC, Ginsberg MH, et al. Structural Basis of Integrin Activation by Talin. Cell (2007) 128 (1):171-82. doi: 10.1016/j.cell.2006.10.048

112. Wynne JP, Wu J, Su W, Mor A, Patsoukis N, Boussiotis VA, et al. Rap1interacting Adapter Molecule (RIAM) Associates With the Plasma Membrane Via a Proximity Detector. J Cell Biol (2012) 199(2):317-30. doi: $10.1083 /$ jcb. 201201157

113. Kliche S, Breitling D, Togni M, Pusch R, Heuer K, Wang X, et al. The ADAP/ SKAP55 Signaling Module Regulates T-Cell Receptor-Mediated Integrin Activation Through Plasma Membrane Targeting of Rap1. Mol Cell Biol (2006) 26(19):7130-44. doi: 10.1128/MCB.00331-06

114. Raab M, Smith X, Matthess Y, Strebhardt K, Rudd CE. SKAP1 Protein PH Domain Determines RapL Membrane Localization and Rap1 Protein Complex Formation for T Cell Receptor (TCR) Activation of LFA-1. J Biol Chem (2011) 286(34):29663-70. doi: 10.1074/jbc.M111.222661
115. Raab M, Wang H, Lu Y, Smith X, Wu Z, Strebhardt K, et al. T Cell Receptor "Inside-Out" Pathway Via Signaling Module SKAP1-RapL Regulates T Cell Motility and Interactions in Lymph Nodes. Immunity (2010) 32(4):541-56. doi: 10.1016/j.immuni.2010.03.007

116. Lefort CT, Rossaint J, Moser M, Petrich BG, Zarbock A, Monkley SJ, et al. Distinct Roles for Talin-1 and Kindlin-3 in LFA-1 Extension and Affinity Regulation. Blood (2012) 119(18):4275-82. doi: 10.1182/blood-2011-08373118

117. Manevich-Mendelson E, Feigelson SW, Pasvolsky R, Aker M, Grabovsky V, Shulman Z, et al. Loss of Kindlin-3 in LAD-III Eliminates LFA-1 But Not VLA-4 Adhesiveness Developed Under Shear Flow Conditions. Blood (2009) 114(11):2344-53. doi: 10.1182/blood-2009-04-218636

118. Moretti FA, Moser M, Lyck R, Abadier M, Ruppert R, Engelhardt B, et al. Kindlin-3 Regulates Integrin Activation and Adhesion Reinforcement of Effector T Cells. Proc Natl Acad Sci USA (2013) 110(42):17005-10. doi: 10.1073/pnas.1316032110

119. Cherry LK, Li X, Schwab P, Lim B, Klickstein LB. Rhoh Is Required to Maintain the Integrin LFA-1 in a Nonadhesive State on Lymphocytes. Nat Immunol (2004) 5(9):961-7. doi: 10.1038/ni1103

120. Wang H, Zeng X, Fan Z, Lim B. Rhoh Modulates Pre-TCR and TCR Signalling by Regulating LCK. Cell Signal (2011) 23(1):249-58. doi: 10.1016/j.cellsig.2010.09.009

121. Gu Y, Chae HD, Siefring JE, Jasti AC, Hildeman DA, Williams DA. Rhoh GTPase Recruits and Activates Zap70 Required for T Cell Receptor Signaling and Thymocyte Development. Nat Immunol (2006) 7(11):1182-90. doi: 10.1038/ni1396

122. Baker CM, Comrie WA, Hyun YM, Chung HL, Fedorchuk CA, Lim K, et al. Opposing Roles for RhoH Gtpase During T-Cell Migration and Activation. Proc Natl Acad Sci USA (2012) 109(26):10474-9. doi: 10.1073/pnas.1114214109

123. Zhang W, Shao Y, Fang D, Huang J, Jeon MS, Liu YC. Negative Regulation of T Cell Antigen Receptor-Mediated Crk-L-C3G Signaling and Cell Adhesion by Cbl-B. J Biol Chem (2003) 278(26):23978-83. doi: 10.1074/ jbc.M212671200

124. Shi J, Cinek T, Truitt KE, Imboden JB. Wortmannin, a Phosphatidylinositol 3-Kinase Inhibitor, Blocks Antigen-Mediated, But Not Cd3 Monoclonal Antibody-Induced, Activation of Murine Cd4+ T Cells. J Immunol (1997) 158(10):4688-95.

125. O'Rourke AM, Shao H, Kaye J. A Role for p21ras/MAP Kinase in TCRMediated Activation of LFA-1. J Immunol (1998) 161(11):5800-3.

126. Zell T, Hunt SW3rd, Mobley JL, Finkelstein LD, Shimizu Y. CD28-Mediated Up-Regulation of Beta 1-Integrin Adhesion Involves Phosphatidylinositol 3Kinase. J Immunol (1996) 156(3):883-6.

127. Chan AS, Mobley JL, Fields GB, Shimizu Y. CD7-Mediated Regulation of Integrin Adhesiveness on Human $\mathrm{T}$ Cells Involves Tyrosine Phosphorylation-Dependent Activation of Phosphatidylinositol 3-Kinase. J Immunol (1997) 159(2):934-42.

128. Garcon F, Okkenhaug K. PI3Kdelta Promotes CD4(+) T-Cell Interactions With Antigen-Presenting Cells by Increasing LFA-1 Binding to ICAM-1. Immunol Cell Biol (2016) 94(5):486-95. doi: 10.1038/icb.2016.1

129. Nombela-Arrieta C, Lacalle RA, Montoya MC, Kunisaki Y, Megias D, Marques $M$, et al. Differential Requirements for DOCK2 and Phosphoinositide-3-Kinase Gamma During T and B Lymphocyte Homing. Immunity (2004) 21(3):429-41. doi: 10.1016/j.immuni.2004.07.012

130. Nombela-Arrieta C, Mempel TR, Soriano SF, Mazo I, Wymann MP, Hirsch E, et al. A Central Role for DOCK2 During Interstitial Lymphocyte Motility and Sphingosine-1-Phosphate-Mediated Egress. J Exp Med (2007) 204(3):497-510. doi: 10.1084/jem.20061780

131. Hawkins PT, Stephens LR. PI3K Signalling in Inflammation. Biochim Biophys Acta (2015) 1851(6):882-97. doi: 10.1016/j.bbalip.2014.12.006

132. Nagel W, Zeitlmann L, Schilcher P, Geiger C, Kolanus J, Kolanus W. Phosphoinositide 3-OH Kinase Activates the Beta2 Integrin Adhesion Pathway and Induces Membrane Recruitment of Cytohesin-1. J Biol Chem (1998) 273(24):14853-61. doi: 10.1074/jbc.273.24.14853

133. Kolanus W, Nagel W, Schiller B, Zeitlmann L, Godar S, Stockinger H, et al. $\alpha 1 \beta 2$ Integrin/LFA-1 Binding to ICAM-1 Induced by Cytohesin-1, A Cytoplasmic Regulatory Molecule. Cell (1996) 86(2):233-42. doi: 10.1016/ s0092-8674(00)80095-1 
134. Nagel W, Schilcher P, Zeitlmann L, Kolanus W. The PH Domain and the Polybasic C Domain of Cytohesin-1 Cooperate Specifically in Plasma Membrane Association and Cellular Function. Mol Biol Cell (1998) 9 (8):1981-94. doi: 10.1091/mbc.9.8.1981

135. Geiger C, Nagel W, Boehm T, van Kooyk Y, Figdor CG, Kremmer E, et al. Cytohesin-1 Regulates Beta-2 Integrin-Mediated Adhesion Through Both ARF-GEF Function and Interaction With LFA-1. EMBO J (2000) 19 (11):2525-36. doi: 10.1093/emboj/19.11.2525

136. Weber KSC, Weber C, Ostermann G, Dierks H, Nagel W, Kolanus W. Cytohesin-1 Is a Dynamic Regulator of Distinct LFA-1 Functions in Leukocyte Arrest and Transmigration Triggered by Chemokines. Curr Biol (2001) 11(24):1969-74. doi: 10.1016/s0960-9822(01)00597-8

137. Quast T, Tappertzhofen B, Schild C, Grell J, Czeloth N, Forster R, et al. Cytohesin-1 Controls the Activation of RhoA and Modulates IntegrinDependent Adhesion and Migration of Dendritic Cells. Blood (2009) 113 (23):5801-10. doi: 10.1182/blood-2008-08-176123

138. El Azreq MA, Garceau V, Bourgoin SG. Cytohesin-1 Regulates fMLFmediated Activation and Functions of the Beta2 Integrin Mac-1 in Human Neutrophils. J Leukoc Biol (2011) 89(6):823-36. doi: 10.1189/jlb.0410222

139. Oh SJ, Santy LC. Differential Effects of Cytohesins 2 and 3 on Betal Integrin Recycling. J Biol Chem (2010) 285(19):14610-6. doi: 10.1074/jbc. M109.043935

140. Oh SJ, Santy LC. Phosphoinositide Specificity Determines Which Cytohesins Regulate Betal Integrin Recycling. J Cell Sci (2012) 125(Pt 13):3195-201. doi: $10.1242 /$ jcs. 101683

141. Jo EK, Wang H, Rudd CE. An Essential Role for SKAP-55 in LFA-1 Clustering on T Cells That Cannot be Substituted by SKAP-55R. J Exp Med (2005) 201(11):1733-9. doi: 10.1084/jem.20042577

142. Menasche G, Kliche S, Chen EJ, Stradal TE, Schraven B, Koretzky G. RIAM Links the ADAP/SKAP-55 Signaling Module to Rap1, Facilitating T-CellReceptor-Mediated Integrin Activation. Mol Cell Biol (2007) 27(11):4070-81. doi: 10.1128/MCB.02011-06

143. Witte A, Meineke B, Sticht J, Philipsen L, Kuropka B, Muller AJ, et al. D120 and K152 Within the PH Domain of T Cell Adapter Skap55 Regulate Plasma Membrane Targeting of SKAP55 and LFA-1 Affinity Modulation in Human T Lymphocytes. Mol Cell Biol (2017) 37(7):MCB.00509-16. doi: 10.1128/ MCB.00509-16

144. Ophir MJ, Liu BC, Bunnell SC. The N Terminus of SKAP55 Enables T Cell Adhesion to TCR and Integrin Ligands Via Distinct Mechanisms. J Cell Biol (2013) 203(6):1021-41. doi: 10.1083/jcb.201305088

145. Svensson L, Howarth K, McDowall A, Patzak I, Evans R, Ussar S, et al. Leukocyte Adhesion Deficiency-III Is Caused by Mutations in KINDLIN3 Affecting Integrin Activation. Nat Med (2009) 15(3):306-12. doi: 10.1038/ nm. 1931

146. Moser M, Bauer M, Schmid S, Ruppert R, Schmidt S, Sixt M, et al. Kindlin-3 Is Required for Beta2 Integrin-Mediated Leukocyte Adhesion to Endothelial Cells. Nat Med (2009) 15(3):300-5. doi: 10.1038/nm.1921

147. Hart R, Stanley P, Chakravarty P, Hogg N. The Kindlin 3 Pleckstrin Homology Domain has an Essential Role in Lymphocyte FunctionAssociated Antigen 1 (LFA-1) Integrin-Mediated B Cell Adhesion and Migration. J Biol Chem (2013) 288(21):14852-62. doi: 10.1074/ jbc.M112.434621

148. Ni T, Kalli AC, Naughton FB, Yates LA, Naneh O, Kozorog M, et al. Structure and Lipid-Binding Properties of the Kindlin-3 Pleckstrin Homology Domain. Biochem J (2017) 474(4):539-56. doi: 10.1042/ BCJ20160791

149. Wen L, Marki A, Roy P, McArdle S, Sun H, Fan Z, et al. Kindlin-3 Recruitment to the Plasma Membrane Precedes High-Affinity Beta2Integrin and Neutrophil Arrest From Rolling. Blood (2021) 137(1):29-38. doi: 10.1182/blood.2019003446

150. Giagulli C, Scarpini E, Ottoboni L, Narumiya S, Butcher EC, Constantin G, et al. Rhoa and Zeta PKC Control Distinct Modalities of LFA-1 Activation by Chemokines: Critical Role of LFA-1 Affinity Triggering in Lymphocyte In Vivo Homing. Immunity (2004) 20(1):25-35. doi: 10.1016/s1074-7613(03) 00350-9

151. Bolomini-Vittori M, Montresor A, Giagulli C, Staunton D, Rossi B, Martinello M, et al. Regulation of Conformer-Specific Activation of the
Integrin LFA-1 by a Chemokine-Triggered Rho Signaling Module. Nat Immunol (2009) 10(2):185-94. doi: 10.1038/ni.1691

152. Takesono A, Horai R, Mandai M, Dombroski D, Schwartzberg PL. Requirement for Tec Kinases in Chemokine-Induced Migration and Activation of Cdc42 and Rac. Curr Biol (2004) 14(10):917-22. doi: 10.1016/j.cub.2004.04.011

153. Labno CM, Lewis CM, You D, Leung DW, Takesono A, Kamberos N, et al. Itk Functions to Control Actin Polymerization at the Immune Synapse Through Localized Activation of Cdc42 and WASP. Curr Biol (2003) 13 (18):1619-24. doi: 10.1016/j.cub.2003.08.005

154. Finkelstein LD, Shimizu Y, Schwartzberg PL. Tec Kinases Regulate TCRMediated Recruitment of Signaling Molecules and Integrin-Dependent Cell Adhesion. J Immunol (2005) 175(9):5923-30. doi: 10.4049/ jimmunol.175.9.5923

155. Huang YH, Grasis JA, Miller AT, Xu R, Soonthornvacharin S, Andreotti AH, et al. Positive Regulation of Itk PH Domain Function by Soluble IP4. Science (2007) 316(5826):886-9. doi: 10.1126/science.1138684

156. Han J, Luby-Phelps K, Das B, Shu X, Xia Y, Mosteller RD, et al. Role of Substrates and Products of PI 3-Kinase in Regulating Activation of RacRelated Guanosine Triphosphatases by Vav. Science (1998) 279(5350):55860. doi: $10.1126 /$ science. 279.5350 .558

157. Krawczyk C, Oliveira-dos-Santos A, Sasaki T, Griffiths E, Ohashi PS, Snapper S, et al. Vav1 Controls Integrin Clustering and MHC/PeptideSpecific Cell Adhesion to Antigen-Presenting Cells. Immunity (2002) 16 (3):331-43. doi: 10.1016/s1074-7613(02)00291-1

158. Prisco A, Vanes L, Ruf S, Trigueros C, Tybulewicz VL. Lineage-Specific Requirement for the PH Domain of Vav1 in the Activation of CD4+ But Not CD8+ T Cells. Immunity (2005) 23(3):263-74. doi: 10.1016/ j.immuni.2005.07.007

159. Herter JM, Rossaint J, Block H, Welch H, Zarbock A. Integrin Activation by P-Rex1 Is Required for Selectin-Mediated Slow Leukocyte Rolling and Intravascular Crawling. Blood (2013) 121(12):2301-10. doi: 10.1182/blood2012-09-457085

160. Reif K, Nobes CD, Thomas G, Hall A, Cantrell DA. Phosphatidylinositol 3Kinase Signals Activate a Selective Subset of Rac/Rho-Dependent Effector Pathways. Curr Biol (1996) 6(11):1445-55. doi: 10.1016/s0960-9822(96) 00749-x

161. Côté J-F, Motoyama AB, Bush JA, Vuori K. A Novel and Evolutionarily Conserved PtdIns(3,4,5)P3-binding Domain Is Necessary for DOCK180 Signalling. Nat Cell Biol (2005) 7(8):797-807. doi: 10.1038/ncb1280

162. Sanematsu F, Nishikimi A, Watanabe M, Hongu T, Tanaka Y, Kanaho Y, et al. Phosphatidic Acid-Dependent Recruitment and Function of the Rac Activator DOCK1 During Dorsal Ruffle Formation. J Biol Chem (2013) 288 (12):8092-100. doi: 10.1074/jbc.M112.410423

163. Sanui T, Inayoshi A, Noda M, Iwata E, Oike M, Sasazuki T, et al. DOCK2 Is Essential for Antigen-Induced Translocation of TCR and Lipid Rafts, But Not PKC-theta and LFA-1, in T Cells. Immunity (2003) 19(1):119-29. doi: 10.1016/s1074-7613(03)00169-9

164. Eppler FJ, Quast T, Kolanus W. Dynamin2 Controls Rap1 Activation and Integrin Clustering in Human T Lymphocyte Adhesion. PloS One (2017) 12 (3):e0172443. doi: 10.1371/journal.pone.0172443

165. Bethoney KA, King MC, Hinshaw JE, Ostap EM, Lemmon MA. A Possible Effector Role for the Pleckstrin Homology (PH) Domain of Dynamin. Proc Natl Acad Sci USA (2009) 106(32):13359-64. doi: 10.1073/pnas.0906945106

166. Jungmichel S, Sylvestersen KB, Choudhary C, Nguyen S, Mann M, Nielsen ML. Specificity and Commonality of the Phosphoinositide-Binding Proteome Analyzed by Quantitative Mass Spectrometry. Cell Rep (2014) 6 (3):578-91. doi: 10.1016/j.celrep.2013.12.038

167. Lockyer PJ, Bottomley JR, Reynolds JS, McNulty TJ, Venkateswarlu K, Potter BV, et al. Distinct Subcellular Localisations of the Putative Inositol 1,3,4,5Tetrakisphosphate Receptors GAP1IP4BP and GAP1m Result From the GAP1IP4BP PH Domain Directing Plasma Membrane Targeting. Curr Biol (1997) 7(12):1007-10. doi: 10.1016/s0960-9822(06)00423-4

168. Kupzig S, Deaconescu D, Bouyoucef D, Walker SA, Liu Q, Polte CL, et al. GAP1 Family Members Constitute Bifunctional Ras and Rap GtpaseActivating Proteins. J Biol Chem (2006) 281(15):9891-900. doi: 10.1074/ jbc.M512802200 
169. Battram AM, Durrant TN, Agbani EO, Heesom KJ, Paul DS, Piatt R, et al. The Phosphatidylinositol 3,4,5-Trisphosphate (PI(3,4,5)P3) Binder Rasa3 Regulates Phosphoinositide 3-Kinase (PI3K)-Dependent Integrin $\alpha$ iib $\beta 3$ Outside-in Signaling. J Biol Chem (2017) 292(5):1691-704. doi: 10.1074/ jbc.M116.746867

170. Brunet A, Bonni A, Zigmond MJ, Lin MZ, Juo P, Hu LS, et al. Akt Promotes Cell Survival by Phosphorylating and Inhibiting a Forkhead Transcription Factor. Cell (1999) 96(6):857-68. doi: 10.1016/s0092-8674(00)80595-4

171. Kops GJ, de Ruiter ND, De Vries-Smits AM, Powell DR, Bos JL, Burgering BM. Direct Control of the Forkhead Transcription Factor AFX by Protein Kinase B. Nature (1999) 398(6728):630-4. doi: 10.1038/19328

172. Charvet C, Canonigo AJ, Becart S, Maurer U, Miletic AV, Swat W, et al. Vav1 Promotes T Cell Cycle Progression by Linking TCR/CD28 Costimulation to FOXO1 and p27kip1 Expression. J Immunol (2006) 177(8):5024-31. doi: 10.4049/jimmunol.177.8.5024

173. Aoki M, Jiang H, Vogt PK. Proteasomal Degradation of the FoxO1 Transcriptional Regulator in Cells Transformed by the P3k and Akt Oncoproteins. Proc Natl Acad Sci USA (2004) 101(37):13613-7. doi: 10.1073/pnas.0405454101

174. Hedrick SM, Hess Michelini R, Doedens AL, Goldrath AW, Stone EL. FOXO Transcription Factors Throughout T Cell Biology. Nat Rev Immunol (2012) 12(9):649-61. doi: 10.1038/nri3278

175. Kerdiles YM, Beisner DR, Tinoco R, Dejean AS, Castrillon DH, DePinho RA, et al. Foxo1 Links Homing and Survival of Naive T Cells by Regulating LSelectin, CCR7 and Interleukin 7 Receptor. Nat Immunol (2009) 10(2):17684. doi: 10.1038/ni.1689

176. Megrelis L, El Ghoul E, Moalli F, Versapuech M, Cassim S, Ruef N, et al. Fam65b Phosphorylation Relieves Tonic Rhoa Inhibition During T Cell Migration. Front Immunol (2018) 9:2001. doi: 10.3389/fimmu.2018.02001

177. Rougerie P, Largeteau Q, Megrelis L, Carrette F, Lejeune T, Toffali L, et al. Fam65b Is a New Transcriptional Target of FOXO1 That Regulates RhoA Signaling for T Lymphocyte Migration. J Immunol (2013) 190(2):748-55. doi: 10.4049/jimmunol.1201174

178. Carlson CM, Endrizzi BT, Wu J, Ding X, Weinreich MA, Walsh ER, et al. Kruppel-Like Factor 2 Regulates Thymocyte and T-Cell Migration. Nature (2006) 442(7100):299-302. doi: 10.1038/nature04882

179. Fabre S, Carrette F, Chen J, Lang V, Semichon M, Denoyelle C, et al. FOXO1 Regulates L-Selectin and a Network of Human T Cell Homing Molecules Downstream of Phosphatidylinositol 3-Kinase. J Immunol (2008) 181 (5):2980-9. doi: 10.4049/jimmunol.181.5.2980

180. Bai A, Hu H, Yeung M, Chen J. Kruppel-Like Factor 2 Controls T Cell Trafficking by Activating L-Selectin (CD62L) and Sphingosine-1-Phosphate Receptor 1 Transcription. J Immunol (2007) 178(12):7632-9. doi: 10.4049/ jimmunol.178.12.7632

181. Skon CN, Lee JY, Anderson KG, Masopust D, Hogquist KA, Jameson SC. Transcriptional Downregulation of S1pr1 Is Required for the Establishment of Resident Memory CD8+ T Cells. Nat Immunol (2013) 14(12):1285-93. doi: 10.1038/ni.2745

182. Galkina E, Tanousis K, Preece G, Tolaini M, Kioussis D, Florey O, et al. LSelectin Shedding Does Not Regulate Constitutive T Cell Trafficking But Controls the Migration Pathways of Antigen-Activated T Lymphocytes. J Exp Med (2003) 198(9):1323-35. doi: 10.1084/jem.20030485

183. Venturi GM, Tu L, Kadono T, Khan AI, Fujimoto Y, Oshel P, et al. Leukocyte Migration Is Regulated by L-Selectin Endoproteolytic Release. Immunity (2003) 19(5):713-24. doi: 10.1016/s1074-7613(03)00295-4

184. Finlay D, Cantrell D. Phosphoinositide 3-Kinase and the Mammalian Target of Rapamycin Pathways Control T Cell Migration. Ann NY Acad Sci (2010) 1183:149-57. doi: 10.1111/j.1749-6632.2009.05134.x

185. Sinclair LV, Finlay D, Feijoo C, Cornish GH, Gray A, Ager A, et al. Phosphatidylinositol-3-OH Kinase and Nutrient-Sensing mTOR Pathways Control T Lymphocyte Trafficking. Nat Immunol (2008) 9(5):513-21. doi: 10.1038/ni.1603

186. Diaz-Rodriguez E, Montero JC, Esparis-Ogando A, Yuste L, Pandiella A. Extracellular Signal-Regulated Kinase Phosphorylates Tumor Necrosis Factor Alpha-Converting Enzyme at Threonine 735: A Potential Role in Regulated Shedding. Mol Biol Cell (2002) 13(6):2031-44. doi: 10.1091/mbc.01-11-0561

187. Fan H, Derynck R. Ectodomain Shedding of TGF-Alpha and Other Transmembrane Proteins Is Induced by Receptor Tyrosine Kinase
Activation and MAP Kinase Signaling Cascades. EMBO J (1999) 18 (24):6962-72. doi: 10.1093/emboj/18.24.6962

188. Soond SM, Everson B, Riches DW, Murphy G. ERK-Mediated Phosphorylation of Thr735 in TNFalpha-Converting Enzyme and Its Potential Role in TACE Protein Trafficking. J Cell Sci (2005) $118(\mathrm{Pt}$ 11):2371-80. doi: $10.1242 /$ jcs.02357

189. Okkenhaug K, Bilancio A, Farjot G, Priddle H, Sancho S, Peskett E, et al. Impaired B and T Cell Antigen Receptor Signaling in P110delta PI 3-Kinase Mutant Mice. Science (2002) 297(5583):1031-4. doi: 10.1126/ science. 1073560

190. Finlay DK, Sinclair LV, Feijoo C, Waugh CM, Hagenbeek TJ, Spits H, et al. Phosphoinositide-Dependent Kinase 1 Controls Migration and Malignant Transformation But Not Cell Growth and Proliferation in PTEN-Null Lymphocytes. J Exp Med (2009) 206(11):2441-54. doi: 10.1084/ jem.20090219

191. Reif K, Okkenhaug K, Sasaki T, Penninger JM, Vanhaesebroeck B, Cyster JG. Cutting Edge: Differential Roles for Phosphoinositide 3-Kinases, p110gamma and pl10delta, in Lymphocyte Chemotaxis and Homing. J Immunol (2004) 173(4):2236-40. doi: 10.4049/jimmunol.173.4.2236

192. Smith LD, Hickman ES, Parry RV, Westwick J, Ward SG. PI3Kgamma Is the Dominant Isoform Involved in Migratory Responses of Human $\mathrm{T}$ Lymphocytes: Effects of Ex Vivo Maintenance and Limitations of NonViral Delivery of Sirna. Cell Signal (2007) 19(12):2528-39. doi: 10.1016/ j.cellsig.2007.08.006

193. Asperti-Boursin F, Real E, Bismuth G, Trautmann A, Donnadieu E. CCR7 Ligands Control Basal T Cell Motility Within Lymph Node Slices in a Phosphoinositide 3-Kinase-Independent Manner. J Exp Med (2007) 204 (5):1167-79. doi: 10.1084/jem.20062079

194. Matheu MP, Deane JA, Parker I, Fruman DA, Cahalan MD. Class IA Phosphoinositide 3-Kinase Modulates Basal Lymphocyte Motility in the Lymph Node. J Immunol (2007) 179(4):2261-9. doi: 10.4049/ jimmunol.179.4.2261

195. Jarmin SJ, David R, Ma L, Chai J-G, Dewchand H, Takesono A, et al. T Cell Receptor-Induced Phosphoinositide-3-Kinase P110 $\delta$ Activity Is Required for T Cell Localization to Antigenic Tissue in Mice. J Clin Invest (2008) 118 (3):1154-64. doi: 10.1172/jci33267

196. Martin AL, Schwartz MD, Jameson SC, Shimizu Y. Selective Regulation of CD8 Effector T Cell Migration by the P110 $\gamma$ Isoform of Phosphatidylinositol 3-Kinase. J Immunol (2008) 180(4):2081-8. doi: 10.4049/jimmunol. 180.4.2081

197. Thomas MS, Mitchell JS, DeNucci CC, Martin AL, Shimizu Y. The p110gamma Isoform of Phosphatidylinositol 3-Kinase Regulates Migration of Effector CD4 T Lymphocytes Into Peripheral Inflammatory Sites. J Leukoc Biol (2008) 84(3):814-23. doi: 10.1189/jlb.0807561

198. Mirenda V, Jarmin SJ, David R, Dyson J, Scott D, Gu Y, et al. Physiologic and Aberrant Regulation of Memory T-Cell Trafficking by the Costimulatory Molecule CD28. Blood (2007) 109(7):2968-77. doi: 10.1182/blood-2006-10-050724

199. Benichou G, Gonzalez B, Marino J, Ayasoufi K, Valujskikh A. Role of Memory T Cells in Allograft Rejection and Tolerance. Front Immunol (2017) 8:170. doi: 10.3389/fimmu.2017.00170

200. Vincenti F, Mendez R, Pescovitz M, Rajagopalan PR, Wilkinson AH, Butt K, et al. A Phase I/II Randomized Open-Label Multicenter Trial of Efalizumab, a Humanized anti-CD11a, anti-LFA-1 in Renal Transplantation. Am J Transplant (2007) 7(7):1770-7. doi: 10.1111/j.1600-6143.2007.01845.x

201. Carson KR, Focosi D, Major EO, Petrini M, Richey EA, West DP, et al. Monoclonal Antibody-Associated Progressive Multifocal Leucoencephalopathy in Patients Treated With Rituximab, Natalizumab, and Efalizumab: A Review From the Research on Adverse Drug Events and Reports (Radar) Project. Lancet Oncol (2009) 10(8):816-24. doi: 10.1016/ S1470-2045(09)70161-5

202. Zhang Q, Lakkis FG. Memory T Cell Migration. Front Immunol (2015) 6:504. doi: 10.3389/fimmu.2015.00504

203. Ying H, Fu H, Rose ML, McCormack AM, Sarathchandra P, Okkenhaug K, et al. Genetic or Pharmaceutical Blockade of Phosphoinositide 3-Kinase p110delta Prevents Chronic Rejection of Heart Allografts. PloS One (2012) 7 (3):e32892. doi: 10.1371/journal.pone.0032892

204. Vilchez V, Turcios L, Butterfield DA, Mitov MI, Coquillard CL, Brandon JA, et al. Evidence of the Immunomodulatory Role of Dual PI3K/mTOR 
Inhibitors in Transplantation: An Experimental Study in Mice. Transpl Int (2017) 30(10):1061-74. doi: 10.1111/tri.12989

205. Yang C, Chen X, Wei Z, Xiao J, Chen W, Shang Y, et al. Targeting the Class IA PI3K Isoforms p110alpha/delta Attenuates Heart Allograft Rejection in Mice by Suppressing the CD4(+) T Lymphocyte Response. Am J Transl Res (2018) 10(5):1387-99.

206. Sang AX, McPherson MC, Ivison GT, Qu X, Rigdon J, Esquivel CO, et al. Dual Blockade of the PI3K/Akt/mTOR Pathway Inhibits Posttransplant Epstein-Barr Virus B Cell Lymphomas and Promotes Allograft Survival. Am J Transplant (2019) 19(5):1305-14. doi: 10.1111/ajt.15216

207. Uehara M, McGrath MM, Ohori S, Solhjou Z, Banouni N, Routray S, et al. Regulation of T Cell Alloimmunity by PI3Kgamma and PI3Kdelta. Nat Commun (2017) 8(1):951. doi: 10.1038/s41467-017-00982-x

208. Klebanoff CA, Gattinoni L, Torabi-Parizi P, Kerstann K, Cardones AR, Finkelstein SE, et al. Central Memory Self/Tumor-Reactive CD8+ T Cells Confer Superior Antitumor Immunity Compared With Effector Memory T Cells. Proc Natl Acad Sci USA (2005) 102(27):9571-6. doi: 10.1073/ pnas. 0503726102

209. Gattinoni L, Klebanoff CA, Palmer DC, Wrzesinski C, Kerstann K, Yu Z, et al. Acquisition of Full Effector Function In Vitro Paradoxically Impairs the In Vivo Antitumor Efficacy of Adoptively Transferred CD8+ T Cells. J Clin Invest (2005) 115(6):1616-26. doi: 10.1172/JCI24480

210. Berger C, Jensen MC, Lansdorp PM, Gough M, Elliott C, Riddell SR. Adoptive Transfer of Effector CD8+ T Cells Derived From Central Memory Cells Establishes Persistent T Cell Memory in Primates. J Clin Invest (2008) 118(1):294-305. doi: 10.1172/JCI32103

211. Restifo NP, Dudley ME, Rosenberg SA. Adoptive Immunotherapy for Cancer: Harnessing the T Cell Response. Nat Rev Immunol (2012) 12 (4):269-81. doi: 10.1038/nri3191

212. Chapuis AG, Thompson JA, Margolin KA, Rodmyre R, Lai IP, Dowdy K, et al. Transferred Melanoma-Specific CD8+ T Cells Persist, Mediate Tumor Regression, and Acquire Central Memory Phenotype. Proc Natl Acad Sci USA (2012) 109(12):4592-7. doi: 10.1073/pnas.1113748109

213. Klebanoff CA, Finkelstein SE, Surman DR, Lichtman MK, Gattinoni L, Theoret MR, et al. IL-15 Enhances the In Vivo Antitumor Activity of TumorReactive CD8+ T Cells. Proc Natl Acad Sci USA (2004) 101(7):1969-74. doi: 10.1073/pnas.0307298101

214. Gattinoni L, Lugli E, Ji Y, Pos Z, Paulos CM, Quigley MF, et al. A Human Memory T Cell Subset With Stem Cell-Like Properties. Nat Med (2011) 17 (10):1290-7. doi: $10.1038 / \mathrm{nm} .2446$

215. Sukumar M, Liu J, Ji Y, Subramanian M, Crompton JG, Yu Z, et al. Inhibiting Glycolytic Metabolism Enhances CD8+ T Cell Memory and Antitumor Function. J Clin Invest (2013) 123(10):4479-88. doi: 10.1172/JCI69589
216. Hurton LV, Singh H, Najjar AM, Switzer KC, Mi T, Maiti S, et al. Tethered IL-15 Augments Antitumor Activity and Promotes a Stem-Cell Memory Subset in Tumor-Specific T Cells. Proc Natl Acad Sci USA (2016) 113(48): E7788-97. doi: 10.1073/pnas.1610544113

217. Van Der Waart AB, Van De Weem NMP, Maas F, Kramer CSM, Kester MGD, Falkenburg JHF, et al. Inhibition of Akt Signaling Promotes the Generation of Superior Tumor-Reactive $\mathrm{T}$ Cells for Adoptive Immunotherapy. Blood (2014) 124(23):3490-500. doi: 10.1182/blood-201405-578583

218. Crompton JG, Sukumar M, Roychoudhuri R, Clever D, Gros A, Eil RL, et al. Akt Inhibition Enhances Expansion of Potent Tumor-Specific Lymphocytes With Memory Cell Characteristics. Cancer Res (2015) 75(2):296-305. doi: 10.1158/0008-5472.CAN-14-2277

219. Majchrzak K, Nelson MH, Bowers JS, Bailey SR, Wyatt MM, Wrangle JM, et al. Beta-Catenin and PI3Kdelta Inhibition Expands Precursor Th17 Cells With Heightened Stemness and Antitumor Activity. JCI Insight (2017) 2 (8):1221. doi: 10.1172/jci.insight.90547

220. Bowers JS, Majchrzak K, Nelson MH, Aksoy BA, Wyatt MM, Smith AS, et al. Pi3kdelta Inhibition Enhances the Antitumor Fitness of Adoptively Transferred Cd8(+) T Cells. Front Immunol (2017) 8:1221. doi: 10.3389/ fimmu.2017.01221

Conflict of Interest: KO has received consultancy fees, speaker fees and/or research support from Gilead Pharmaceuticals, Karus Therapeutics and GlaxoSmithKline.

The remaining authors declare that the research was conducted in the absence of any commercial or financial relationships that could be construed as a potential conflict of interest.

Publisher's Note: All claims expressed in this article are solely those of the authors and do not necessarily represent those of their affiliated organizations, or those of the publisher, the editors and the reviewers. Any product that may be evaluated in this article, or claim that may be made by its manufacturer, is not guaranteed or endorsed by the publisher.

Copyright (๑) 2021 Johansen, Golec, Thomsen, Schwartzberg and Okkenhaug. This is an open-access article distributed under the terms of the Creative Commons Attribution License (CC BY). The use, distribution or reproduction in other forums is permitted, provided the original author(s) and the copyright owner(s) are credited and that the original publication in this journal is cited, in accordance with accepted academic practice. No use, distribution or reproduction is permitted which does not comply with these terms. 